OPEN ACCESS

Edited by:

Fernando Ponz,

Instituto Nacional de Investigación y

Tecnología Agraria y Alimentaria (INIA),

Spain

Reviewed by:

Marie-Theres Hauser,

Universität für Bodenkultur Wien,

Austria

Carmen Arena

Università degli Studi di Napoli

Federico II, Italy

${ }^{*}$ Correspondence:

Jachym Suman

jachym.suman@vscht.cz

Specialty section:

This article was submitted to

Plant Biotechnology,

a section of the journal

Frontiers in Plant Science

Received: 02 May 2018

Accepted: 20 September 2018

Published: 16 October 2018

Citation:

Suman J, Uhlik O, Viktorova J and Macek T (2018) Phytoextraction of Heavy Metals: A Promising Tool for Clean-Up of Polluted Environment?

Front. Plant Sci. 9:1476.

doi: 10.3389/fpls.2018.01476

\section{Phytoextraction of Heavy Metals: A Promising Tool for Clean-Up of Polluted Environment?}

\author{
Jachym Suman*, Ondrej Uhlik, Jitka Viktorova and Tomas Macek \\ Department of Biochemistry and Microbiology, Faculty of Food and Biochemical Technology, University of Chemistry and \\ Technology, Prague, Czechia
}

Pollution by heavy metals $(H M)$ represents a serious threat for both the environment and human health. Due to their elemental character, HM cannot be chemically degraded, and their detoxification in the environment mostly resides either in stabilization in situ or in their removal from the matrix, e.g., soil. For this purpose, phytoremediation, i.e., the application of plants for the restoration of a polluted environment, has been proposed as a promising green alternative to traditional physical and chemical methods. Among the phytoremediation techniques, phytoextraction refers to the removal of $\mathrm{HM}$ from the matrix through their uptake by a plant. It possesses considerable advantages over traditional techniques, especially due to its cost effectiveness, potential treatment of multiple HM simultaneously, no need for the excavation of contaminated soil, good acceptance by the public, the possibility of follow-up processing of the biomass produced, etc. In this review, we focused on three basic HM phytoextraction strategies that differ in the type of plant species being employed: natural hyperaccumulators, fast-growing plant species with high-biomass production and, potentially, plants genetically engineered toward a phenotype that favors efficient HM uptake and boosted HM tolerance. Considerable knowledge on the applicability of plants for HM phytoextraction has been gathered to date from both lab-scale studies performed under controlled model conditions and field trials using real environmental conditions. Based on this knowledge, many specific applications of plants for the remediation of HM-polluted soils have been proposed. Such studies often also include suggestions for the further processing of HM-contaminated biomass, therefore providing an added economical value. Based on the examples presented here, we recommend that intensive research be performed on the selection of appropriate plant taxa for various sets of conditions, environmental risk assessment, the fate of HM-enriched biomass, economical aspects of the process, etc.

Keywords: heavy metals, phytoremediation, phytoextraction, hyperaccumulators, genetically modified plants, heavy metal protein transporters, heavy metal binding proteins, green biotechnology

\section{INTRODUCTION}

With the industrialization and urbanization of developing countries and the increasing demands of mankind, the consumption of heavy metal elements (HM, see Glossary) has been growing enormously. As a result, pollution by HM and metalloids (see Glossary) has become an increasingly serious issue, which has raised public awareness. Unlike organic pollutants, which can be entirely, 


\section{GLOSSARY}

Heavy Metal There is not yet a consensus definition of the term "heavy metal" (HM). Nevertheless, the most recent criterion suggested defines HMs as naturally occurring metals having atomic number $>20$ and elemental density $>5 \mathrm{~g} . \mathrm{cm}^{-3}$ (Ali and Khan, 2018). In biological sciences, this term instead describes a series of metallic elements and metalloids with a potential toxic effect on living organisms even at very low concentrations. From this toxicological/ecotoxicological standpoint, chemical properties and behavior in living systems are a more important criterion. Therefore, in addition to transition metal elements such as Cd, Pb, Hg, Zn, Cu, Co, $\mathrm{Ni}, \mathrm{Al}, \mathrm{Cr}$, Fe, the metalloids As, Se or Sb can also be regarded as "heavy metals."

Phytoremediation The use of plants for the restoration of a polluted environment. Generally, there are two principal strategies for decreasing HM toxicity in soils: site stabilization (including phytostabilization techniques) and "clean-up" techniques (including phytoextraction and phytovolatilization techniques).

Phytostabilization The use of plants for the reduction of HM toxicity in soil through reducing their mobility/bioavailability.

Phytoextraction The use of plants for HM removal from the contaminated matrix (soil and water) through their uptake into the harvestable parts of the plant.

Hyperaccumulation The ability of a plant to accumulate HMs in its above-ground parts without phytotoxic symptoms at concentrations up to 100-1,000-fold higher than in non-hyperaccumulating species (Baker, 1981). Such an ability resides in (i) enhancement of the uptake of HMs from the rhizosphere across the root cell plasma membrane, (ii) reduction of the sequestration of HMs in root-cell vacuoles, (iii) enhancement of the loading of HMs into the xylem for transport to shoots, and (iv) stimulation of HM influx across the leaf cell plasma membrane and sequestration in the leaf (mesophyll cells) vacuoles (Milner and Kochian, 2008).

Phytomining The use of plants for the in situ removal of HMs from sub-economic ore bodies, metalliferous soils or from contaminated mine sites with the additional aim of recovering an economic amount of metals from the plants [according to Sheoran et al. (2009)].

"Gene-Stacking" Strategy (also "Gene-Pyramiding" Strategy) The expression or manipulation of multiple (trans)genes in a single plant line [for review see Halpin (2005)]. This process provides the potential to accumulate multiple traits, typically multiple resistance to different types of stress or pathogen. As discussed in the text, this can also provide a tool for obtaining a plant variety suitable for efficient HM phytoextraction.

Short-Rotation Forestry/Plantation System The concept of culturing woody plants (especially fast-growing trees such as willow, poplar, pine, aspen, birch, beech, eucalyptus, etc.) or annually-harvested energy crops for energy production.

Trangenosis A gene-technology breeding method of introducing a transgene, which is according to Jacobsen and Schouten (2009) a (synthetic) gene with some or all regulatory sequences and coding sequences from donors other than crossable plants, including microorganisms and animals. Transgenes comprise a new gene pool for plant breeding.

Cisgenesis A gene technology breeding method of introducing a cisgene, which is according to Jacobsen and Schouten (2009) an already existing natural gene from the plant taxon itself or from crossable species, including its native promoter and terminator. The gene belongs to the traditional breeder gene pool and is the already existing result of natural evolution.

Intragenesis A gene technology breeding method of introducing an intragene, which is according to Jacobsen and Schouten (2009) a gene comprising of natural functional elements, such as the coding part, promoter and terminator originating from different genes from the plant taxon itself or from crossable species. All natural gene elements belong to the traditional breeder gene pool.

or partly degraded by the action of various (micro)organisms or detoxified by the action of plants, HM are non-degradable and can only be transformed into forms with altered toxicity and/or mobility/bioavailability (e.g., bacterial reduction of $\mathrm{Hg}^{2+}$ to elementary $\mathrm{Hg}^{0}$ that is less toxic and can evaporate, or the reduction of arsenate to less toxic arsenite oxyanions; Silver and Phung, 2005; Silver and Phung le, 2005). The persistence of $\mathrm{HM}$ in environmental matrices, especially soils, sediments and water bodies, is a result of the elemental character of HM (Chapman et al., 1996). Pollution by HM therefore represents a long-term threat for the environment and human health, not only in industrial and post-industrial areas.

Conventional physical and chemical methods of HM removal from a polluted environment are usually not usable at large scales, and are often costly and not well accepted by the public [for a recent review see Khalid et al. (2017)]. In contrast, bioremediation i.e., the use of living organisms or their parts for remediation, is a group of methods that are highly applicable in large contaminated areas, especially in cases where the removal of HM contamination is not urgent. The use of plants for the decontamination of a polluted environment has been termed phytoremediation and was described in the mid-90s (Sandermann, 1994; Cunningham et al., 1995; Schnoor et al., 1995; Cunningham and Ow, 1996). Ever since, a vast number of studies have focused on the employment of various plant species for the removal or stabilization of both organic and inorganic pollutants (for reviews see Salt et al., 1998; Macek et al., 2000; Mackova et al., 2006a,b; Marmiroli et al., 2006; Cristaldi et al., 2017; Wang et al., 2017).

Generally, the most yet-employed strategies on how to remediate an HM-polluted environment are based either on their stabilization in situ, i.e., reducing HM acute toxicity through decreasing their mobility and bioavailability (so-called "site stabilization" techniques), or are based on HM removal (the group of "clean-up" techniques). When using plants, the first group is referred to by the term phytostabilization (see Glossary). Among the clean-up techniques, phytoextraction employs plants for the extraction of HM from soils and their accumulation in harvestable parts, which are subsequently removed and further processed (Baker et al., 1994; Salt et al., 1995, 1998; Chaney et al., 1997). Phytovolatilization, another subgroup of clean-up techniques, represents the conversion of $\mathrm{HM} /$ metalloids such as $\mathrm{Hg}$, As, and Se into a volatile form via biological conversion within plants, and their release into the atmosphere (Rugh et al., 1996; Raskin et al., 1997; He et al., 2001; Che et al., 2003; Tangahu et al., 2011). Despite decreasing the pollution locally, this group of techniques contributes to the pool of mobile forms transportable over long distances, and is somewhat controversial (Prasad and Freitas, 2003).

Over the last three decades, great progress has been made in researching the applicability of phytoremediation techniques, 
including the use both of natural varieties and genetically modified (GM) plants. Therefore, in this review, we discuss the use of plants for the phytoextraction of HM and metalloids from soils. Particular attention is paid to the prospective employment of genetic modifications leading to plant varieties with a phenotype favoring HM phytoextraction from polluted sites.

\section{HYPERACCUMULATORS}

Baker (1981) defined two main strategies adopted by plants naturally growing on metalliferous sites based on the strategy of survival. Excluders, representing the majority of plant species capable of surviving in soils containing elevated levels of toxic trace elements, have adopted the survival strategy of maximal exclusion of HM ions from the plant. If an HM ion is taken up by an excluder plant, the toxic effect is restricted to the roots, where it is detoxified, while the aerial parts remain more or less unaffected. In contrast, hyperaccumulators are plants which, when exposed to elevated concentrations of HM, are able to accumulate them in their above-ground parts without phytotoxicity symptoms (Baker, 1981; Rascio and Navari-Izzo, 2011; van der Ent et al., 2013). The term hyperaccumulator was first applied when describing the New Caledonian $\mathrm{Ni}^{-}$ accumulating tree Sebartia acuminata (Sapotaceae); the nickel content in the latex was determined to be $26 \%$ percent of dry weight (Jaffré et al., 1976). According to Baker and Brooks (1989), the content limits of some metal elements in dry biomass for plants to be termed hyperaccumulators are $100 \mathrm{mg} \cdot \mathrm{kg}^{-1}$ for $\mathrm{Cd}$ and Se, 1,000 mg. $\mathrm{kg}^{-1}$ for $\mathrm{Co}, \mathrm{Cu}, \mathrm{Ni}$ and $\mathrm{Pb}$, and $10,000 \mathrm{mg} \cdot \mathrm{kg}^{-1}$ for $\mathrm{Zn}$ and $\mathrm{Mn}$. These values are up to 100-1,000-fold higher than for non-hyperaccumulating species under the same conditions (Reeves, 2006; Rascio and Navari-Izzo, 2011). The number of identified hyperaccumulators has been constantly rising, with over 450 HM-hyperaccumulating species known as of 2015, found in 45 angiosperm families (Rascio and Navari-Izzo, 2011; Bhargava et al., 2012; Krzciuk and Gałuszka, 2015). About 25\% of hyperaccumulators identified so far recruit from the family Brassicaceae; other families rich in hyperaccumulators include Asteraceae, Euphorbiaceae, Rubiaceae, Fabaceae, Scrophulariacea, Myrtaceae, Proteaceae, Caryophylaceae, Tiliaceae, etc. (Reeves, 2006; Rascio and Navari-Izzo, 2011). Some plant genera appear to include a significant proportion of hyperaccumulator species; e.g., in studies comprehensively surveying the genus Alyssum, 48 out of 170 species tested were found to hyperaccumulate $\mathrm{Ni}$ (Brooks and Radford, 1978; Brooks et al., 1979). Interestingly, hyperaccumulation ability was found to vary within a species; metal specificity and accumulation can vary among different populations (Reeves et al., 2001; Assuncao et al., 2008).

As stated by Milner and Kochian (2008), who surveyed the $\mathrm{Zn}, \mathrm{Cd}$ and $\mathrm{Ni}$ model hyperaccumulator alpine pennycress (Noccaea caerulescens, formerly Thlaspi caerulescens), several crucial physiological steps of HM detoxification are different in hyperaccumulators compared to non-hyperaccumulators. These are (i) boosted HM ions uptake from the rhizosphere across the root cell plasma membrane, (ii) reduced HM ions sequestration in root vacuoles, (iii) intensified HM ions loading into the xylem for transport to shoots, and (iv) stimulated HM ions influx across the leaf cell plasma membrane and (v) sequestration in the leaf vacuole. Nevertheless, a considerable contribution of cell wall components, especially low-methylesterified pectins, in the sequestration of HM ions within a plant body was also proposed (for reviews, see Krzesłowska, 2011; Le Gall et al., 2015). Leitenmaier and Küpper (2013) concluded that the key factor for hyperaccumulation is the plant's enhanced active metal transport rather than strengthened metal complexation by various intracellular ligands (such as glutathione, phytochelatins, or metallothioneins). Similarly, cross-species transcriptomic and genome-wide analyses of the extremophilic Zn- and Cd-hyperaccumulator Arabidopsis halleri revealed an enrichment in HM-transporting P-ATPAse HMA4 gene copies and corresponding transcripts as well as other transition metal homeostasis and biotic stress function genes compared to the non-accumulating sister species Arabidopsis lyrata and closely related reference model species Arabidopsis thaliana (Hanikenne et al., 2008; Suryawanshi et al., 2016). More detailed information on the various tolerance strategies of plants under HM stress and on hyperaccumulators, their taxonomic and geographical distribution, metal specificity as well as molecular mechanisms behind hyperaccumulation have been provided by Reeves (2006); Verbruggen et al. (2009); Rascio and Navari-Izzo (2011); Leitenmaier and Küpper (2013); van der Ent et al. (2013); Krzciuk and Gałuszka (2015), and Singh et al. (2016).

\section{PHYTOEXTRACTION-A TOOL FOR THE REMEDIATION OF HM-POLLUTED SITES?}

In order to be suitable for phytoextraction purposes, plant species should meet the following criteria: (i) metallotolerance toward elements present in toxic levels, (ii) high biomass production and (iii) effective accumulation of HM in easy-toharvest parts (Vangronsveld et al., 2009). The overall concept of the restoration of polluted areas using phytoextraction consists of the cultivation of appropriate plant species in situ, harvesting the HM-containing biomass and treating it to decrease its volume and weight (by composting, compacting, drying, thermal decomposition). The resultant HM-enriched mass containing high levels of metal contaminants is subsequently disposed of as a hazardous waste or, if economically advantageous, can be utilized for the re-extraction of trace elements (McGrath et al., 2002; Sheoran et al., 2009). In general, three basic strategies can be considered for HM phytoextraction, differing in the type of plant species used: (i) natural hyperaccumulators, (ii) fastgrowing plant species with high-biomass production, and (iii) genetically engineered plants, all of which are discussed below. Advantages and drawbacks of these strategies are summarized in Table 1.

Several criteria should be taken into account when evaluating the suitability of a plant species for HM phytoextraction, in particular the quantitative ability of each plant species to accumulate HM in harvestable parts, and the overall production of biomass which can be expressed by the biomass yield per crop and number of crops per year. McGrath and Zhao (2003) 
TABLE 1 | Benefits and drawbacks of HM phytoextraction employing natural hyperaccumulators, high-biomass producing non-hyperaccumulators or genetically engineered plants.

\begin{tabular}{|c|c|c|c|}
\hline & Natural hyperaccumulators & $\begin{array}{l}\text { High-biomass producing } \\
\text { non-hyperaccumulators }\end{array}$ & Genetically engineered plant \\
\hline Advantages & $\begin{array}{l}\text { High bioaccumulation rates } \\
\text { Often autochtonic species-prevents } \\
\text { the introduction of non-native and } \\
\text { potentially invasive species }\end{array}$ & $\begin{array}{l}\text { High biomass production rate, possibility of } \\
\text { production of biomass with added value } \\
\text { Low growth requirements } \\
\text { Possible use in short-rotation plantation } \\
\text { Number of species convenient for diverse } \\
\text { range of climatic conditions, water regime, soil } \\
\text { type, character of contamination } \\
\text { Often autochthonic species-prevents the } \\
\text { introduction of non-native and potentially } \\
\text { invasive species } \\
\text { Usually low metal/toxicant } \\
\text { specificity-applicability for mixed contamination } \\
\text { (both multiple HM and mixture of HM and } \\
\text { organic xenobiotics) }\end{array}$ & $\begin{array}{l}\text { Possibility of directed engineering of } \\
\text { metallophenotype toward high } \\
\text { bioconcentration factor } \\
\text { Number of (trans)genes available for } \\
\text { modification, possibility of organ/tissue-specific } \\
\text { transgene expression enabling modulation of } \\
\text { resultant phenotype } \\
\text { Possible stacking of multiple phenotypical traits } \\
\text { Possibility of selection of host plant species } \\
\text { (depending on the intended fate or use of } \\
\text { resulting HM-enriched biomass) }\end{array}$ \\
\hline Disadvantages & $\begin{array}{l}\text { High metal specificity (often only } \\
\text { single heavy metal element } \\
\text { hyperaccumulated) } \\
\text { Often slowly growing, low-biomass } \\
\text { producing species, with specific } \\
\text { ecology and requirements in terms of } \\
\text { climate, soil characteristics, water } \\
\text { regime, etc. }\end{array}$ & $\begin{array}{l}\text { Low bioaccumulation rates-lengthy } \\
\text { phytoextraction process }\end{array}$ & $\begin{array}{l}\text { Often high metal specificity depending on } \\
\text { (trans)gene/genetic modification } \\
\text { Lack of information from field trials performed } \\
\text { on large areas in terms of overall applicability } \\
\text { (economical aspects, efficiency of the process, } \\
\text { management of HM-enriched biomass } \\
\text { produced) } \\
\text { GMO-linked environmental risks and related } \\
\text { strict GMO regulation policy, thorough } \\
\text { ecological risk assessment needed }\end{array}$ \\
\hline
\end{tabular}

determined that for economically feasible phytoextraction, the use of a plant with a metal bioconcentration factor, defined as the ratio of $\mathrm{HM}$ concentration in the plant to the soil, higher than 20 and biomass yield of $10 \mathrm{t} \cdot \mathrm{ha}^{-1}$ is required, or with a bioconcentration factor of 10 and biomass production of $20 \mathrm{t} \cdot \mathrm{ha}^{-1}$ (Peuke and Rennenberg, 2005). Other criteria to be considered are the depth of the contaminated layer (if the contamination is deeper than $20-30 \mathrm{~cm}$, deep-rooting woody species should be utilized), the intended fate of HM-enriched biomass (e.g., re-extraction of metal elements; biofuel, energy and fiber production), climatic and soil conditions, etc. (Brooks et al., 1998; Mench et al., 2009; Sheoran et al., 2009).

The toxic element and its bioavailable concentration in the polluted matrix (soil) also needs to be considered, as well as the ability of a plant to maintain photosynthetic activity and biomass production even under HM-induced stress. If a toxicant content is too high, it can exceed the plant's tolerance level, especially for non-hyperaccumulator species, resulting in toxic symptoms and reduced photosynthetic capability and, consequently, lower biomass yield and reduced phytoextraction performance of a plant. Therefore, a systematic experimental assessment of HM-induced alterations in biomass production, plant anatomy, morphology, photosynthetic, and transpiration rate, photosynthetic pigments content, GSH-content, activity of reactive oxygen species (ROS)-defense enzymes, etc. should be preferably performed during the evaluation of a plant's suitability for HM phytoextraction, as was done with poplar (Populus sp.) (Ivanova et al., 2011; Chandra and Kang, 2016), eucalyptus (Eucalyptus camaldulenses) (Gomes et al., 2012), flax
(Linnum ussitatissimum) and China aster (Callistephus chinensis) (Kavuličová et al., 2012), cardoon (Cynara cardunculus) (Arena et al., 2017; Sorrentino et al., 2018), rapeseed (Brassica napus) (Benáková et al., 2017), etc.

\section{Phytoextraction Employing High-Biomass Non-accumulators}

The employment of fast-growing deep-rooting woody species such as willow (Salix spp.) and Populus spp. is a reasonable choice for phytoextraction (Unterbrunner et al., 2007). These taxa are able to produce a high amount of biomass in a relatively short time, have a high rate of water uptake and transpiration, have a deep root system, can be effectively and rapidly reproduced through re-sprouting, and their aboveground parts are easy to harvest. Importantly, Unterbrunner et al. (2007) discovered that $\mathrm{Zn}$ and $\mathrm{Cd}$ are preferentially accumulated in the leaves and not in the wood of these taxa; HM can be therefore continuously removed from the site by harvesting leaf biomass. Additionally, covering the remediated area with hardy vegetation prevents the erosion and transfer of contaminated material to the surrounding environment (i.e., plants act as phytostabilizers). Another major advantage of using non-edible woody species for HM cleanup is the biomass produced during the phytoextraction process which can provide an added economic value if used, for instance, in energy production (short-rotation forestry system concept; Einspahr, 1976a,b; Nixon et al., 2001; Volk et al., 2004; Hinchee et al., 2009; Kidd et al., 2015). For instance, experiments with cotton (Gossypium sp.) plants grown in a former industrial area in Bulgaria near Plovdiv contaminated with HMs demonstrated 
that after treating the produced cotton fiber with boiling water, the $\mathrm{Cd}, \mathrm{Zn}, \mathrm{Cu}$, and $\mathrm{Pb}$ content was diminished to levels comparable to the plant material grown in non-contaminated sites. These findings make cotton another crop suitable for sustainable long-term use in contaminated areas (Yankov et al., 2000). Vangronsveld et al. (2009) demonstrated the potential of biomass for biofuel and biogas production despite the fact that the phytoextraction efficiency in their field trial, in which they employed Z. mays, tobacco (Nicotiana tabacum), B. napus and sunflower (Helianthus annuus), was not very encouraging (the estimated time required for clean-up of agricultural land moderately contaminated with $\mathrm{Cd}$ and $\mathrm{Zn}$ ranged from 29 years for tobacco to 234 years for rapeseed). An interesting approach to the subsequent utilization of HM-contaminated biomass produced during a phytoextraction process was applied in the studies of Zheljazkov and Nielsen (1996a,b). Medicinal plants such as peppermint (Mentha piperita) and lavender (Lavandula angustifolia) were proven to accumulate moderate levels of HM in the harvested biomass, and at the same time the aromatic oil produced from this contaminated biomass was contaminant free.

Several different clones of willows have been found to accumulate substantial amounts of $\mathrm{Cd}$ and $\mathrm{Zn}$ (Greger and Landberg, 1999). A field experiment performed with a Cdaccumulating clone of Salix viminalis cultivated in sludgeamended soil demonstrated that the total amount of extracted $\mathrm{Cd}$ (expressed as weight of $\mathrm{Cd}$ removed per ha and y) was ca $5 \times$ and $6 \times$ higher than the hyperaccumulating species Alyssum murale and $N$. caerulescens, respectively (Greger and Landberg, 1999). A large-scale field experiment performed on a site moderately contaminated with $\mathrm{Cd}$ and $\mathrm{Zn}$ in Lommel (Belgium) employed different clones of Populus sp. and Salix sp. for the phytoextraction of $\mathrm{Cd}$. According to the most optimistic estimation based on the output data, from 12.5 up to 25 years would be needed for the restoration of a site with a Cd content of $1 \mathrm{mg} \cdot \mathrm{kg}^{-1}$ soil (experiments reviewed in Vangronsveld et al., 2009). The influence of clone choice and the necessity of foliage harvesting were also highlighted in the two above-mentioned studies, as well as in the study of Vyslouzilova et al. (2006). Another field trial employing a short-rotation coppice of willow grown in metal-contaminated agricultural soil demonstrated the ability of a Salix coppice to remove $72 \mathrm{~g} \mathrm{Cd}$ and $2 \mathrm{~kg} \mathrm{Zn} \mathrm{ha}{ }^{-1}$ year $^{-1}$, values much higher than maize (Zea mays) or B. napus grown in the same soil (Van Slycken et al., 2013b).

$Z$. mays has been also widely surveyed for its potential employment in the management of HM-contaminated soil due to its rapid growth, high biomass production and general Cd-tolerance. In a field-scale trial conducted on an area of Cd-contaminated farmland in China, Z. mays was shown to accumulate up to $3 \mathrm{mg} \cdot \mathrm{kg}^{-1}$ of dry biomass while maintaining grain $\mathrm{Cd}$ concentrations under the Chinese government's limit for coarse cereals (Xu et al., 2013). Van Slycken et al. (2013a) adopted $\mathrm{Z}$. mays for the management of $\mathrm{Cd}, \mathrm{Zn}, \mathrm{Pb}$ and Ascontaminated agricultural land. In their study, Z. mays was shown to remove on average $19 \mathrm{~g} \mathrm{Cd} \mathrm{ha}^{-1} \cdot$ year $^{-1}$ and $4.3 \mathrm{~kg} \mathrm{Zn}$ $\mathrm{ha}^{-1}$.year ${ }^{-1}$ with the biomass produced being comparable with $Z$. mays grown in non-contaminated soil in the same region. Moreover, the Cd content in the harvested biomass did not exceed European threshold values for animal feed. The use of biomass for biogas production was also demonstrated, with the production values being unaffected by the HM content. The issue of employing $Z$. mays for the phytoextraction of HMcontaminated soils was comprehensibly reviewed by Rizwan et al. (2017). The employment of other high-biomass-producing nonhyperaccumulating plants for trace element extraction have been also reported, both from small- and large-scale field experiments (for a comprehensive review see Vangronsveld et al., 2009).

A more advanced approach of employing plants for the cleanup of soil, proposed by Macci et al. (2013), is to take advantage of the synergic action of trees, shrubs and grasses. In their recent study, Macci et al. (2016) investigated the real-scale clean-up of a former industrial area polluted with a mixed contamination of HMs, hydrocarbons and polychlorinated biphenyls. Three different woody plants were employed, namely Populus sp., empress tree (Paulownia tomentosa), and the perennial shrub Scotch broom (Cytisus scoparius), in combination with naturally growing vegetation and the addition of organic matter (horse manure). Within 2 years, vegetation with any of the three species resulted in the reduction of both organic and HM contamination (average reduction of about 35, 40, and $70 \%$ in the soil content of HMs, hydrocarbons and PCBs, respectively); moreover, soil functionality was also recovered during the remediation.

\section{Phytoextraction Employing Hyperaccumulators}

In a vast number of published manuscripts, hyperaccumulators have been shown to possess an exceptional ability to take up HMs from soil and store them in aerial plant organs, a trait that is seemingly promising for employment in phytoextraction. For instance, the study of Robinson et al. (1998) summarized that phytoextraction using $N$. carulescens would be entirely feasible for low Cd soil levels; since plants reached values of bioaccumulation coefficients of about 60 and 10 for $1 \mathrm{mg} \cdot \mathrm{kg}^{-1}$ and $50 \mathrm{mg} \cdot \mathrm{kg}^{-1} \mathrm{Cd}$ in soil, respectively, only a single harvest would be needed to halve a soil Cd content of $10 \mathrm{mg} \cdot \mathrm{kg}^{-1}$. Unlike $\mathrm{Cd}$, the remediation of $\mathrm{Zn}$ was not found to be feasible within an economic time frame (i.e., $<10$ years) because of the low $\mathrm{Zn}$ bioaccumulation coefficients (bellow 1) achieved at higher soil $\mathrm{Zn}$ levels. Similar conclusions were made by Nishiyama et al. (2005), whose study performed with $N$. caerulescens grown at a $\mathrm{Cd}$ soil concentration of $5 \mathrm{mg} \cdot \mathrm{kg}^{-1}$ indicated that only about 2 - 6 harvests (depending on the soil type, Fluvisol or Andosol) could decrease the Cd concentration to 50\%. Moreover, field trials conducted on urban HM-contaminated soil by Jacobs et al. (2017) using N. caerulescens, showed that Cd and Zn removal from soil was in a range that is already practically applicable for phytoextraction (Cd and $\mathrm{Zn}$ uptake values of $200 \mathrm{~g} \cdot \mathrm{ha}^{-1}$ and $47 \mathrm{~kg} \cdot \mathrm{ha}^{-1}$, respectively).

Other hyperaccumulating taxa have been proposed to be employable for HM removal from soils (Sarma, 2011). For instance, $B$. juncea was reported to effectively remove $\mathrm{Cd}, \mathrm{Cr}$, $\mathrm{Cu}, \mathrm{Ni}, \mathrm{Pb}$, and $\mathrm{Zn}$ from a hydroponic medium (Dushenkov et al., 1995), hydrophyte water hyacinth (Eichhornia crassipes) 
was able to efficiently accumulate $\mathrm{Cd}, \mathrm{Cr}, \mathrm{Cu}$, and $\mathrm{Se}$, especially in roots. Similarly, the perennial shrub Sesbania drummondii, a $\mathrm{Pb}$ hyperaccumulator, exhibited an ability to uptake $\mathrm{Pb}$ (shoot concentrations of $>4 \% \mathrm{~Pb}$ in hydroponic culture) while maintaining a high biomass yield (Sahi et al., 2002).

An example of an extension of hyperaccumulator-based HM phytoextraction providing an added economical value is phytomining (see Glossary). The field study by Robinson et al. (1997) was performed on ultramafic soils in Italy with the autochthonic Ni hyperaccumulator Alyssum bertolonii. The authors showed that this perennial might be used for the economically feasible phytomining of $\mathrm{Ni}$, providing up to $72 \mathrm{~kg}$ Ni.ha ${ }^{-1}$ without the need to resow for a further crop. Similarly, field trials with $A$. murale recovered up to $112 \mathrm{~kg} \mathrm{Ni}^{-h^{-1}}$ in a single crop (Robinson et al., 1997; Bani et al., 2015a,b).

\section{Green Biotechnology Application-GM Plants With Enhanced HM Tolerance and Phytoextraction Efficiency}

As was shown above, the use of plants might represent an economically- and ecologically-friendly alternative to conventional techniques for the decontamination/stabilization of HM-polluted sites. However, some features limit their successful use, including (i) low biomass production of many natural hyperaccumulators and (ii) low phytoextraction efficiency of plant species that, on the other hand, fulfill the required technological parameters such as high growth rate and biomass production. Therefore, the use of such a convenient plant species, but purposely genetically engineered to the "hyperaccumulator-like" phenotype (e.g., with increased HM accumulation in aboveground parts and HM tolerance), seems to be a sustainable way to utilize plants for the decontamination of polluted matrices. A general strategy for the production of such bioengineered plants has been reviewed elsewhere, for instance by Bhargava et al. (2012).

If the resultant genetically engineered plant is intended for the decontamination of HM-polluted matrices, the aim of the transgenosis is to modify the distribution of accumulated HM throughout the plant body. HM should be preferentially translocated into above-ground parts that can be easily harvested, and the plant's growth rate should not be reduced as the result of HM accumulation. Hence, sustaining root-to-shoot translocation (HM loading into xylem vessels) and subsequent vacuolization and/or sequestration in the cells of the plant aerial parts account for the most frequently employed strategies to create hyperaccumulator-like plant varieties (for more detailed reviews on the topic, see e.g., Bhargava et al., 2012; Mosa et al., 2016).

In addition to HM removal from polluted matrices, enhanced HM uptake and translocation into aboveground parts via genetic modifications has been also proposed to increase the concentration of trace elements (such as $\mathrm{Fe}, \mathrm{Zn}, \mathrm{Cu}, \mathrm{Se}$ ) in biomass for nutritional purposes when grown in noncontaminated sites (biofortification). For instance, transgenic wheat (Triticum aestivum) expresing gene OsNAS2 encoding for nicotianamine synthase 2 from rice (Oryza sativa) was shown to attain dietary significant levels of $\mathrm{Zn}$ and Fe in grains (Singh et al., 2017). Similarly, authors Wu et al. (2018) used combination of three genes AtNAS1 encoding for nicotianamine synthase 1 from A. thaliana, AtFRD3 (transporter loading xylem with citrate-iron complex) and PvFER (ferritin from bean Phaseolus vulgaris) resulting in increased $\mathrm{Zn}$ and $\mathrm{Fe}$ content in grains of resultant multi-transgenic lines of $O$. sativa. A trial with O. sativa expressing a cisgene (see Glossary) OsNAS2 and a transgene SferrH-1 encoding for ferritin from soybean (Glycine max) proved biofortification of grains with $\mathrm{Fe}$ and $\mathrm{Zn}$ even under field conditions without any concomitant contamination with other harmful HM (Trijatmiko et al., 2016). The topic of biofortification via genetic modification was reviewed in Palmgren et al. (2008) and Borrill et al. (2014).

\section{HM Protein Transporters}

As mentioned previously, enhanced HM translocation across biological membranes most likely denotes a fundamental physiological process determining the hyperaccumulation ability of a plant. HM transport in plants includes transport through both the cytoplasmic membrane (apoplasm/symplasm interphase, e.g., uploading/unloading xylem vessels) and tonoplast and, possibly, borders of other intracellular compartments (Leitenmaier and Küpper, 2013). Alteration of these processes via genetic modification therefore appears to be an option to develop a plant variety suitable for HM phytoextraction and such genetic modifications have been frequently employed. Yeast cadmium factor protein YCF (a vacuolar glutathione S-conjugate pump and a member of the ATP-binding cassette transporter family associated with multi-drug resistance) is an example of a HM protein transporter used for transgenosis (Li et al., 1996). For instance, in the study of Bhuiyan et al. (2011b) the YCF1 gene was introduced into $B$. juncea and the resultant transformants exhibited enhanced tolerance to $\mathrm{Cd}$ and $\mathrm{Pb}$ and also an increased accumulation of these HMs in shoots (about 1.5- to 2-fold compared to the wild type). The same gene was employed by Shim et al. (2013) for hybrid Populus sp. transgenosis. Upon Cd exposure, the resultant plants exhibited enhanced growth, reduced $\mathrm{Cd}$ toxicity symptoms, and increased $\mathrm{Cd}$ content in the aerial tissue compared to non-transgenic plants. Furthermore, the plants accumulated more $\mathrm{Cd}, \mathrm{Zn}$, and $\mathrm{Pb}$ in roots because they were able to establish an extensive root system in HM-contaminated mine tailing soil. Similarly, B. juncea plants expressing AtATM3, another mitochondrial membrane $\mathrm{ABC}$ transporter involved in the biogenesis of Fe-S clusters and iron homeostasis in thale cress (Arabidopsis thaliana), exhibited increased $\mathrm{Cd}$ and $\mathrm{Pb}$ tolerance and shoot accumulation (about 1.5- to 2.5-fold higher compared to the wild type). These changes in metallophenotype were attributed to increased expression levels of intrinsic glutathione synthetase II and phytochelatin synthase 1 induced by AtATM3 overexpression (Bhuiyan et al., 2011a).

Bacterial HM-protein transporters is another vast pool of molecules potentially employable for transgenosis in order to increase phytoextraction efficiency. Wu et al. (2011) reported ectopic expression of mutated variant of $C A X 1$ gene from A. thaliana encoding for $\mathrm{Ca}^{2+} / \mathrm{H}^{+}$antiporter in petunia 
$($ Petunia $\times$ hybrida). CAX1-bearing plants exhibited up to 2.5fold greater $\mathrm{Cd}$ tolerance and accumulation compared to the control. Furthermore, an exemplary study demonstrated that the introduction of a bacterial HM transporter PbtA into a yeast resulted in an increased accumulation of $\mathrm{Pb}, \mathrm{Zn}$, and $\mathrm{Cd}$, and this transporter is further suggested to be employed for plant transgenosis aiming at increased phytoextraction efficiency and higher resistance of the plant (Suman et al., 2014). More examples of HM transporters employed in plant transgenosis are listed the Table 2.

\section{Protein/Peptidic HM Chelators and Low-Molecular Binding Agents}

Another strategy adopted to artificially enhance the HM accumulation capacity and tolerance of plants is through increased levels of HM binding agents in planta. Generally, it is hypothesized that the cell capacity to accumulate HM should be enhanced via the increased intracellular production of HM-ions binding sites, along with increasing metalloresistance through avoiding the appearance of "free" metal ions in the plant. Several examples of specific genetic determinants introduced into various plant species with the aim of increasing intracellular metal-chelating compounds can be found in Table 2 . A frequently investigated approach is exemplified by the overproduction of peptidic chelators such as glutathione (GSH) and phytochelatins (PC) through the overexpression of the enzymes of their biosynthetic pathways. An example of an effort to increase intracellular GSH content is the overexpression of genes encoding for $\gamma$-glutamylcysteine synthetase $(\gamma$-ECS) and cysteine synthetase (GS), of both bacterial and eukaryotic origin (Liang Zhu et al., 1999; Koprivova et al., 2002; Bittsánszky et al., 2005; Li et al., 2006b; Zhao et al., 2010). These enzymes catalyze two ATP-dependent reactions: the formation of $\gamma$ glutamylcysteine $(\gamma$-ES) from glutamate and cysteine and the addition of glycine at the C-terminal end of $\gamma$-ES, respectively, yielding GSH (Meister, 1988). For instance, in the pioneering work of Noctor et al. (1996), transgenic Populus sp. bearing $\gamma$-ECS (gsh1) from E. coli were generated. Foliar $\gamma$-ES and glutathione content increased $10-$ and 3-fold, respectively, without affecting either the general physiological parameters of the transgenic plants or the reduction state of the glutathione pool and the foliar cysteine content. Several other studies were published employing genes for either $\gamma$-ECS or GS, or both simultaneously, for the alteration of the metallophenotype of plant species such as B. juncea (Liang Zhu et al., 1999; Zhu et al., 1999), Populus sp. (Koprivova et al., 2002; Bittsánszky et al., 2005), A. thaliana (Li et al., 2006b), creeping bentgrass (Agrostis palustris) (Zhao et al., 2010), etc. The resultant (double-)transgenic plants generally exhibited an increased rate of tolerance and accumulation of HMs such as Cd (Liang Zhu et al., 1999; Zhu et al., 1999; Koprivova et al., 2002; Zhao et al., 2010), Zn (Bittsánszky et al., 2005), or Hg (Li et al., 2006b).

A similar approach to increase the pool of HM-binding thiol compounds is the introduction of phytochelatin synthase (PCS), an enzyme catalyzing the formation of PC from the precursor $\gamma$-ES (Ha et al., 1999; Clemens and Persoh, 2009). PCS-encoding genes predominantly of plant origin were used for the transgenosis, leading to enhanced HM accumulation and tolerance (Table 2; Li et al., 2006a; Martínez et al., 2006; Guo et al., 2008; Liu et al., 2012; Shukla et al., 2012).

Unlike GSH and PCs, metallothioneins (MT) are geneencoded metal binding proteins with multiple functions in planta, including metal homeostasis (for a comprehensive review, see Leszczyszyn et al., 2013). These small proteins have been found to exert HM binding capacity in vivo including $\mathrm{Zn}, \mathrm{Cd}$ and $\mathrm{Cu}$, when heterologously and ectopically expressed (Kille et al., 1991; Tommey et al., 1991; Evans et al., 1992; Abdullah et al., 2002). In addition to the inspection of their physiological function, a possible use of MT for enhancing metalloresistance and/or the accumulation capacity of GM plants was proposed by several authors (Thomas et al., 2003; Zhang et al., 2006; Krystofova et al., 2012). Nevertheless, the effect of such ectopic and heterologous expression on the metallophenotype is rather difficult to predict; accumulation and tolerance patterns differ among metal elements and across studies (for instance Krystofova et al., 2012 vs. Thomas et al., 2003, Table 2). Since in the majority of studies MT imparted an increased metallotolerance to the resultant transgenic plants together with an enhanced retention of the studied HM in roots, MT are more likely to be employed in protecting plants against HM stress in contaminated locations rather than for metallocrop preparation (Krystofova et al., 2012).

A study by Pianelli et al. (2005) investigated another metal ligand molecule, nicotianamine, an ubiquitous nonproteinogenic amino acid biosynthesized from methionine, involved in plant $\mathrm{Fe}$ homeostasis and able to bind various other metals as well (Rudolph et al., 1985). A. thaliana plants overexpressing nicotianamine synthase cDNA (NAS1) from the $N$. caerulescens exhibited an up to 100-fold higher accumulation of nicotianamine in their tissue and higher Ni tolerance and accumulation than the control. The authors proposed this gene to be introduced into suitable high-biomass plant species in combination with a HM-complex root-to-shoot translocator (e.g., yellow stripe 1, YSL1; Curie et al., 2001) in order to enhance the root-to-shoot ratio of accumulated metal and therefore "move" the metal to harvestable parts.

\section{"Gene Stacking" Strategy}

The term "gene stacking" (or "gene pyramiding") refers to the simultaneous expression or manipulation of multiple transgenes in a single GM plant or hybrid variety (Halpin, 2005). The accumulation of traits leading to an increased HM uptake and storage in harvestable parts and/or increased metalloresistance represents an advanced approach to modifying the plant metallophenotype for use in HM phytoextraction. In the study by Li et al. (2006b), A thaliana hybrid plants of two singletransgenic lines bearing $\gamma$-ECS and GS were prepared, and their metallophenotype was compared to the parental one. Enhanced PC levels in roots as well as increased $\mathrm{Hg}$ tolerance and accumulation was observed for the ECS/GS co-expressing lines achieving a $\mathrm{Hg}$ bioconcentration factor as high as 600 . Similar findings by Guo et al. (2008) showed that dual-transgenic A. thaliana plants overexpressing both PCS and $\gamma$-ECS (derived from garlic and yeasts, respectively) led to elevated PC levels and 
TABLE 2 | Exemplary studies dealing with GM plants with altered HM tolerance and/or accumulation ability.

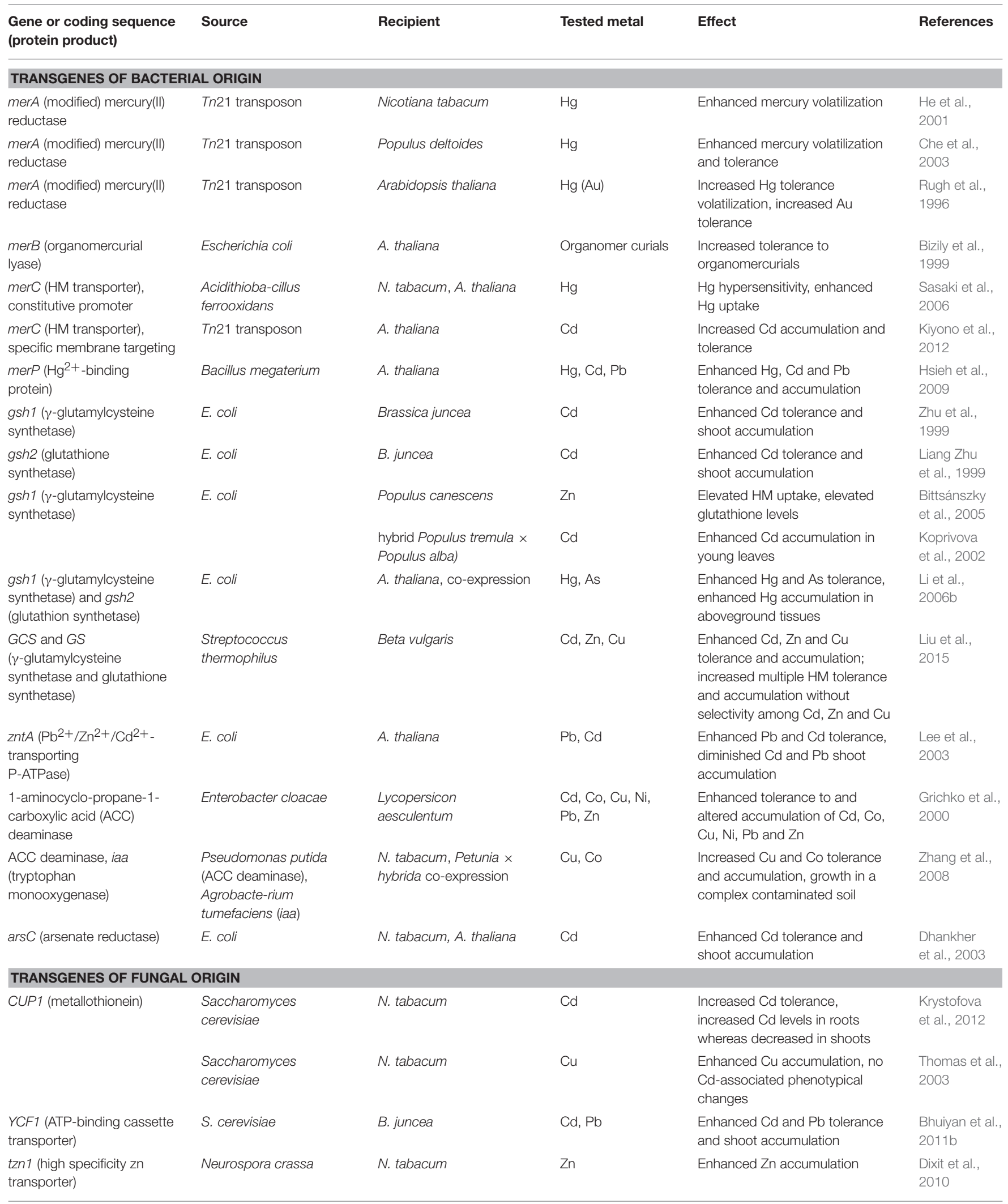


TABLE 2 | Continued

\begin{tabular}{|c|c|c|c|c|c|}
\hline $\begin{array}{l}\text { Gene or coding sequence } \\
\text { (protein product) }\end{array}$ & Source & Recipient & Tested metal & Effect & References \\
\hline \multicolumn{6}{|c|}{ TRANSGENES OF PLANT ORIGIN } \\
\hline \multirow[t]{4}{*}{$\begin{array}{l}\text { PCS1 (phytochelatin } \\
\text { synthase) }\end{array}$} & Thlaspi arvense & Nicotiana glauca & $\mathrm{Cd}, \mathrm{Zn}, \mathrm{Pb}, \mathrm{Cu}$ & $\begin{array}{l}\text { Enhanced HM accumulation, } \\
\text { high biomass production in real } \\
\text { mining soil experiment }\end{array}$ & $\begin{array}{l}\text { Martínez } \\
\text { et al., } 2006\end{array}$ \\
\hline & $\begin{array}{l}\text { Ceratophyllum } \\
\text { demersum }\end{array}$ & N. tabacum & $\mathrm{Cd}$, As & $\begin{array}{l}\text { Enhanced } \mathrm{Cd} \text { and As root } \\
\text { accumulation }\end{array}$ & $\begin{array}{l}\text { Shukla et al., } \\
2012\end{array}$ \\
\hline & Nelumbo nucifera & A. thaliana & $\mathrm{Cd}$ & Enhanced Cd accumulation & $\begin{array}{l}\text { Liu et al., } \\
2012\end{array}$ \\
\hline & Cynodon dactylon & N. tabacum & $\mathrm{Cd}$ & $\begin{array}{l}\text { Increase Cd tolerance and } \\
\text { accumulation }\end{array}$ & $\begin{array}{l}\text { Li et al., } \\
2006 a\end{array}$ \\
\hline $\begin{array}{l}\text { GCS ( } \gamma \text {-glutamylcysteine } \\
\text { synthetase) }\end{array}$ & Phragmites australis & Agrostis stolonifera & $\mathrm{Cd}$ & $\begin{array}{l}\text { Increased Cd tolerance and } \\
\text { accumulation }\end{array}$ & $\begin{array}{l}\text { Zhao et al., } \\
2010\end{array}$ \\
\hline $\begin{array}{l}\text { CBP4 (calmodulin-binding } \\
\text { channel-like protein) }\end{array}$ & N. tabacum & $\begin{array}{l}\text { N. tabacum } \\
\text { overexpression }\end{array}$ & $\mathrm{Ni}, \mathrm{Pb}$ & $\begin{array}{l}\text { Increased } \mathrm{Ni} \text { tolerance } \mathrm{Pb} \text { and } \\
\text { hypersensitivity, reduced } \mathrm{Ni} \text { and } \\
\text { enhanced } \mathrm{Pb} \text { accumulation }\end{array}$ & $\begin{array}{l}\text { Arazi et al., } \\
1999\end{array}$ \\
\hline $\begin{array}{l}\text { MRP7 (ATP-binding } \\
\text { cassette transporter) }\end{array}$ & A. thaliana & N. tabacum & $\mathrm{Cd}$ & $\begin{array}{l}\text { Increased Cd tolerance, } \\
\text { decreased Cd root-to-shoot } \\
\text { translocation, enhanced Cd } \\
\text { accumulation in leaf vacuoles }\end{array}$ & $\begin{array}{l}\text { Wojas et al., } \\
2009\end{array}$ \\
\hline $\begin{array}{l}\text { ATM3 (ATP-binding } \\
\text { cassette transporter) }\end{array}$ & A. thaliana & B. juncea & $\mathrm{Cd}, \mathrm{Pb}$ & $\begin{array}{l}\text { Increased } \mathrm{Cd} \text { and } \mathrm{Pb} \text { tolerance } \\
\text { and accumulation }\end{array}$ & $\begin{array}{l}\text { Bhuiyan et al., } \\
2011 \text { a }\end{array}$ \\
\hline $\begin{array}{l}\text { CET3, CET4 (cation-efflux } \\
\text { transporters) }\end{array}$ & B. juncea & $\begin{array}{l}\text { N. tabacum, } \\
\text { co-expression }\end{array}$ & $\mathrm{Cd}$ & $\begin{array}{l}\text { Enhanced Cd tolerance, altered } \\
\text { Cd accumulation }\end{array}$ & $\begin{array}{l}\text { Lang et al., } \\
2011\end{array}$ \\
\hline $\begin{array}{l}\text { ACBP1 (acylCoA-binding } \\
\text { protein) }\end{array}$ & A. thaliana & A. thaliana overexpression & $\mathrm{Pb}$ & $\begin{array}{l}\text { Enhanced } \mathrm{Pb} \text { tolerance and } \\
\text { shoot accumulation }\end{array}$ & $\begin{array}{l}\text { Xiao et al., } \\
2008\end{array}$ \\
\hline \multicolumn{6}{|c|}{ TRANSGENES OF OTHER ORIGIN } \\
\hline MTII (clas II metallothionein) & Homo sapiens sapiens & N. tabacum & $\mathrm{Cd}$ & $\begin{array}{l}\text { Decreased Cd levels in leaves } \\
\text { whereas increased in roots and } \\
\text { stems }\end{array}$ & $\begin{array}{l}\text { de Borne } \\
\text { et al., } 1998\end{array}$ \\
\hline $\begin{array}{l}\text { Pseudophytochelatin } \\
\text { Met(GluCys) } 6 \text { Gly }\end{array}$ & Synthetic & N. tabacum & $\mathrm{Cd}$ & $\begin{array}{l}\text { Enhanced Cd tolerance and } \\
\text { shoot accumulation }\end{array}$ & $\begin{array}{l}\text { Postrigan } \\
\text { et al., } 2012\end{array}$ \\
\hline
\end{tabular}

exhibited significantly higher $\mathrm{Cd} /$ As tolerance and accumulation than single transgenic and non-transgenic controls (about 2.5 times and 10 times higher for the two elements, respectively).

Synergy in the function of two genes expressed simultaneously was also shown in the work of Grispen et al. (2011). A. thaliana genes AtMT2b and AtHMA4 encoding for a IIbclass metallothionein and a stellar $\mathrm{Zn}^{2+}$ - and $\mathrm{Cd}^{2+}$-transporting ATPase, respectively, were introduced into N. tabacum plants, and the double transformants exhibited enhanced Cd tolerance (ca 2-fold), enhanced $\mathrm{Cd} / \mathrm{Zn}$ root-to-shoot transport, but unaltered $\mathrm{Zn}$ tolerance and overall $\mathrm{Cd} / \mathrm{Zn}$ uptake, compared with both non-transgenic and single-transgenic controls. Hence, the authors highlighted the synergy between two genes introduced into plants. Since the observed metallophenotype was altered only moderately, they suggested (especially for the HMA4 gene) the use of the A. thaliana native promoter of the 
HMA4 gene instead of the constitutive cauliflower mosaic virus promoter and, possibly, the introduction of multiple transgene copies. Both proposed modifications should imitate the intrinsic tissue/organ localization and regulation of those found in the natural hyperaccumulator rockcress Arabidopsis halleri (Hanikenne et al., 2008).

\section{Phytoextraction of HM Using GM Plants in the Field?}

Several articles comprehensively reviewing the issue of the potential employment of GM plants in HM phytoremediation have been released over the last decade (Cherian and Oliveira, 2005; Macek et al., 2008, 2009, 2013; Kotrba et al., 2009; Sarma, 2011; Bhargava et al., 2012; Ibañez et al., 2016). A number of various transgenes of both bacterial and eukaryotic origin have been employed (examples are listed in Table 2), predominantly in lab-scale studies on model plant species such as N. tabacum, A. thaliana, or tomato (Lycopersicon esculentum). In the majority of published studies, HM removal and tolerance experiments were only performed under model controlled conditions, typically in "ideal" agar-based or hydroponic cultures with only one metal element being examined in a single experiment; only a few studies were performed on a mixture of different metal elements, investigating interactions between the metals (e.g., Liu et al., 2015). Moreover, only several studies have moved from model conditions to pot-scale experiments, some of which were performed in real HM-contaminated soil (Bennett et al., 2003; Heaton et al., 2003; Pavlikova et al., 2004; Martínez et al., 2006; Rodriguez et al., 2008; Pilon-Smits and Leduc, 2009; Shim et al., 2013). Nevertheless, the "giant leap for mankind," i.e., remediation experiments performed under field conditions, was shown to be indispensable for the reliable assessment of the applicability of GM plants for phytoremediation. The effect of examined genetic determinants on the phenotype can be severely influenced by real conditions in situ, including the co-occurrence of other organic and inorganic contaminants as many different contaminating metal elements tend to occur simultaneously (Banerjee et al., 1999), the bioavailability of micro- and macronutrients, soil type, content of organic matter, climatic conditions, interactions with other (micro)organisms, etc.

Among the few published studies that meet the requirement of in situ testing, Bañuelos et al. (2005) showed that GM plants can perform efficiently under field conditions. In their work, three different transgenic lines of $B$. juncea plants were planted in a field plot with a layer of Se, B and salt contaminated sediment covered with a layer of non-contaminated nutrientrich soil and cultivated under continuous irrigation for 45 days. Even after this relatively short time period, plants bearing genes encoding for adenosine triphosphate sulfurylase (APS), $\gamma$-ECS and GS were able to accumulate 4.3-, 2.8-, and 2.3-fold more Se, respectively, in their shoots than the control, with the first value theoretically corresponding to $4.4 \%$ of the total extractable Se present in the contaminated drainage sediment. The aerial biomass produced was significantly lower than with control plants cultivated in the pristine soil (about $80 \%$ for GS plants), but still about $50 \%$ higher than for the wild-type strain kept in the polluted soil. Even though the duration of this field trial was short, the results indicated the potential of such GM plants for Se-phytoremediation.

The aforementioned work of Shim et al. (2013) was another study performed under real field conditions. It assessed the phytoextraction potential of transgenic Populus sp. plants hybrids of $P$. alba $\times P$. tremula var. glandulosa $\mathrm{BH} 1$ (non-flowering mutant clone) harboring the yeast HM transporter gene Ycf1. During the field experiment, pre-cultivated cuttings of Ycf1plants were kept in pots containing diluted $\mathrm{Zn}$ mine tailing soil under the open sky for a period of over 6 months. During this period, Ycf1-plants accumulated approximately 4-6 times more $\mathrm{Cd}$ in their shoots than non-GM control plants, while maintaining the same biomass production. The root system of GM plants was even more developed. Although these findings looked promising in terms of the use of the $Y c f 1$-plants for the removal of $\mathrm{Cd}, \mathrm{Zn}$, As, and $\mathrm{Pb}$ from soils, the authors did not support this idea. The bioconcentration factor of the $Y c f 1$ plants of Populus sp. under field conditions was calculated to be only 0.3 for $\mathrm{Cd}, 0.9$ for $\mathrm{Zn}, 0.2$ for $\mathrm{As}$, and 1.9 for $\mathrm{Pb}$, values in strong contrast with those found for the hydroponic culture also surveyed in the study. The minimal bioconcentration factor value essential for effective short-term remediation (i.e., in time-span of ca 10 crops) using these specific Ycf1-bearing plants was estimated to be around 14. Nevertheless, the authors proposed the possible application of those GM plants for long-term phytoextraction with concurrent phytostabilization of polluted sites. The entire study was an example of a possible discrepancy between results obtained under hydroponic and real soil conditions, which needs to be considered before making conclusions about the potential applicability of any "GM plants with enhanced phytoextraction efficiency." On the other hand, the field trial carried out by Bañuelos et al. (2005) with GM $B$. juncea described above basically confirmed the data obtained in their previous studies performed under model conditions (Liang Zhu et al., 1999; Pilon-Smits et al., 1999; Zhu et al., 1999).

\section{CONCLUSIONS AND FUTURE PERSPECTIVES}

The first vector and bacterial strain system that enabled the introduction of genetic modifications into plants emerged in 1985 (Deblaere et al., 1985). Over the next three decades, the process of transgenosis has become routinely used for the generation of GM plants with many different goals. The methods of genetic engineering have provided us with a powerful tool for producing a vast number of model GM plants, thereby enormously contributing to our understanding of HM homeostasis and detoxification, ROS-defense systems, etc.

The possibility of employing GM plants for the clean-up of HM-contaminated matrices has been intensively researched, a number of plant taxa bearing transgenes of various origins and presumptive functions have been surveyed. As summarized herein, many studies proved that the resultant transgenic plants manifested metallophenotypes making such an approach promising for use in phytoextraction. Nevertheless, the actual 
use of GM plants for soil clean-up has been relatively limited. Only several published GM varieties fulfill the requirements for phytoextraction efficiency that would allow the clean-up process to be feasible in terms of time and costs.

However, GM varieties have been so far almost solely prepared for research purposes that examine the usability of a genetic determinant, incorporating no more than pot-scale or controlled field experiments. As a result, their direct introduction into the environment is rather controversial, since they do not meet the requirements for modern GM organisms, i.e., the absence of a selection marker gene and vector backbone, the site-specific character of genetic modification, the use of genes from an evolutionary close gene pool (see Glossary for cisgenesis or intragenesis), etc. Further improvements are required in the genesis of new GM varieties, which would allow both the development of plants with superior metallophenotypes, and their commercialization even in countries where GM organisms are poorly accepted (Kamthan et al., 2016). Recent advances in the genome editing system CRISPR/Cas9 have enabled highly site-specific modifications of many plant genomes, and has therefore become a powerful tool for the development of selectable-marker-free transgenic hyperaccumulators potentially more suitable for real conditions (for recent reviews, see Bortesi and Fischer, 2015; Liu et al., 2017).

At the same time, a more thorough assessment of the risks related to the introduction of GM plants into the environment is indispensable prior to their use in the field (Hilbeck et al., 2011; Sanvido et al., 2012). With GM plants intended for phytoextraction, such risks include gene-flow from transgenics which could quantitatively reduce the genetic

\section{REFERENCES}

Abdullah, S. N. A., Cheah, S. C., and Murphy, D. J. (2002). Isolation and characterisation of two divergent type 3 metallothioneins from oil palm, Elaeis guineensis. Plant Physiol. Biochem. 40, 255-263. doi: 10.1016/S0981-9428(02)01366-9

Ali, H., and Khan, E. (2018). What are heavy metals? Long-standing controversy over the scientific use of the term 'heavy metals' - proposal of a comprehensive definition. Toxicol. Environ. Chem. 100, 6-19. doi: 10.1080/02772248.2017.1413652

Arazi, T., Sunkar, R., Kaplan, B., and Fromm, H. (1999). A tobacco plasma membrane calmodulin-binding transporter confers $\mathrm{Ni} 2+$ tolerance and $\mathrm{Pb} 2+$ hypersensitivity in transgenic plants. Plant J. 20, 171-182. doi: 10.1046/j.1365-313x.1999.00588.x

Arena, C., Figlioli, F., Sorrentino, M. C., Izzo, L. G., Capozzi, F., Giordano, S., et al. (2017). Ultrastructural, protein and photosynthetic alterations induced by $\mathrm{Pb}$ and $\mathrm{Cd}$ in Cynara cardunculus L., and its potential for phytoremediation. Ecotoxicol. Environ. Saf. 145, 83-89. doi: 10.1016/j.ecoenv.2017.07.015

Assuncao, A. G. L., Bleeker, P., ten Bookum, W. M., Vooijs, R., and Schat, H. (2008). Intraspecific variation of metal preference patterns for hyperaccumulation in Thlaspi caerulescens: evidence from binary metal exposures. Plant Soil 303, 289-299. doi: 10.1007/s11104-007-9508-x

Baker, A. J. M. (1981). Accumulators and excluders-strategies in the response of plants to heavy-metals. J. Plant Nutr. 3, 643-654. doi: 10.1080/01904168109362867

Baker, A. J. M., and Brooks, R. R. (1989). Terrestrial higher plants which hyperaccumulate metallic elements-a review of their distribution, ecology and phytochemistry. Biorecovery 1, 81-126. diversity of both wild and domesticated relatives, the horizontal transfer of transgenes into non-relative organisms including prokaryotes e.g., through cross-pollination, Agrobacteriummediated transformation with naked DNA, etc. (EFSA Panel On Geneticlay Modified Organisms (GMO), 2010; Tsatsakis et al., 2017). We also propose another environmental risk to be considered prior to field applications of both natural and transgenic hyperaccumulators-the toxicity of HM-enriched biomass and subsequent impact on wildlife in situ, including herbivores, natural enemies, pollinators, decomposers, microbial symbionts, and overall biodiversity.

Finally, as shown above in this article, recent field studies have demonstrated that some hyperaccumulators meet the requirements for utilization in a real phytoextraction process, especially for their enormous HM bioaccumulation rates being far higher than those of high-biomass non-hyperaccumulators including those from genus Salix, Populus, etc. With more effort put into more modern GM techniques, the performance of many plant taxa can be further improved and efficiently used for large-scale phytoextraction purposes in real locations.

\section{AUTHOR CONTRIBUTIONS}

All authors listed have made a substantial, direct and intellectual contribution to the work, and approved it for publication.

\section{FUNDING}

Funding from the Czech Science Foundation via grant 15-22276S is gratefully acknowledged.

Baker, A. J. M., McGrath, S. P., Sidoli, C. M. D., and Reeves, R. D. (1994). The possibility of in situ heavy metal decontamination of polluted soils using crops of metal-accumulating plants. Resour. Conserv. Recycl. 11, 41-49. doi: 10.1016/0921-3449(94)90077-9

Banerjee, K., Helwick, R. P., and Gupta, S. (1999). A treatment process for removal of mixed inorganic and organic arsenic species from groundwater. Environ. Progr. 18, 280-284. doi: 10.1002/ep.670180415

Bani, A., Echevarria, G., Sulce, S., and Morel, J. L. (2015a). Improving the agronomy of alyssum murale for extensive phytomining: a five-year field study. Int. J. Phytoremed. 17 (1-6), 117-127. doi: 10.1080/15226514.2013.862204

Bani, A., Echevarria, G., Zhang, X., Benizri, E., Laubie, B., Morel, J. L., et al. (2015b). The effect of plant density in nickel-phytomining field experiments with Alyssum murale in Albania. Austral. J. Botany 63, 72-77. doi: 10.1071/BT14285

Bañuelos, G., Terry, N., Leduc, D. L., Pilon-Smits, E. A. H., and Mackey, B. (2005). Field trial of transgenic Indian mustard plants shows enhanced phytoremediation of selenium-contaminated sediment. Environ. Sci. Technol. 39, 1771-1777. doi: 10.1021/es049035f

Benáková, M., Ahmadi, H., Ducaiova, Z., Tylova, E., Clemens, S., and Tuma, J. (2017). Effects of $\mathrm{Cd}$ and $\mathrm{Zn}$ on physiological and anatomical properties of hydroponically grown Brassica napus plants. Environ. Sci. Pollution Res. 24, 20705-20716. doi: 10.1007/s11356-017-9697-7

Bennett, L. E., Burkhead, J. L., Hale, K. L., Terry, N., Pilon, M., and PilonSmits, E. A. H. (2003). Analysis of transgenic Indian mustard plants for phytoremediation of metal-contaminated mine tailings. J. Environ. Qual. 32, 432-440. doi: 10.2134/jeq2003.4320

Bhargava, A., Carmona, F. F., Bhargava, M., and Srivastava, S. (2012). Approaches for enhanced phytoextraction of heavy metals. J. Environ. Manage. 105, 103-120. doi: 10.1016/j.jenvman.2012.04.002 
Bhuiyan, M. S. U., Min, S. R., Jeong, W. J., Sultana, S., Choi, K. S., Lee, Y., et al. (2011a). Overexpression of AtATM3 in Brassica juncea confers enhanced heavy metal tolerance and accumulation. Plant Cell Tissue Organ Culture 107, 69-77. doi: 10.1007/s11240-011-9958-y

Bhuiyan, M. S. U., Min, S. R., Jeong, W. J., Sultana, S., Choi, K. S., Song, W. Y., et al. (2011b). Overexpression of a yeast cadmium factor 1 (YCF1) enhances heavy metal tolerance and accumulation in Brassica juncea. Plant Cell Tissue Organ Culture 105, 85-91. doi: 10.1007/s11240-010-9845-y

Bittsánszky, A., Kömives, T., Gullner, G., Gyulai, G., Kiss, J., Heszky, L., et al. (2005). Ability of transgenic poplars with elevated glutathione content to tolerate $\operatorname{zinc}\left(2^{+}\right)$stress. Environ. Int. 31, 251-254. doi: 10.1016/j.envint.2004.10.001

Bizily, S. P., Rugh, C. L., Summers, A. O., and Meagher, R. B. (1999). Phytoremediation of methylmercury pollution: merB expression in Arabidopsis thaliana confers resistance to organomercurials. Proc. Natl. Acad. Sci. U.S.A. 96, 6808-6813. doi: 10.1073/pnas.96.12.6808

Borrill, P., Connorton, J. M., Balk, J., Miller, A. J., Sanders, D., and Uauy, C. (2014). Biofortification of wheat grain with iron and zinc: integrating novel genomic resources and knowledge from model crops. Front. Plant Sci. 5:53. doi: 10.3389/fpls.2014.00053

Bortesi, L., and Fischer, R. (2015). The CRISPR/Cas9 system for plant genome editing and beyond. Biotechnol. Adv. 33, 41-52. doi: 10.1016/j.biotechadv.2014.12.006

Brooks, R. R., Chambers, M. F., Nicks, L. J., and Robinson, B. H. (1998). Phytomining. Trends Plant Sci. 3, 359-362. doi: 10.1016/S1360-1385(98)01283-7

Brooks, R. R., Morrison, R. S., Reeves, R. D., Dudley, T. R., and Akman, Y. (1979). Hyper-accumulation of nickel by Alyssum linnaeus (Cruciferae). Proc. R. Soc. B Biol. Sci. 203, 387-403. doi: 10.1098/rspb.1979.0005

Brooks, R. R., and Radford, C. C. (1978). Nickel accumulation by European species of genus Alyssum. Proc. R. Soc. B Biol. Sci. 200, 217-224. doi: $10.1098 / \mathrm{rspb} .1978 .0016$

Chandra, R., and Kang, H. (2016). Mixed heavy metal stress on photosynthesis, transpiration rate, and chlorophyll content in poplar hybrids. Forest Sci. Technol. 12, 55-61. doi: 10.1080/21580103.2015.1044024

Chaney, R. L., Malik, M., Li, Y. M., Brown, S. L., Brewer, E. P., Angle, J. S., et al. (1997). Phytoremediation of soil metals. Curr. Opin. Biotechnol. 8, 279-284. doi: 10.1016/S0958-1669(97)80004-3

Chapman, P. M., Thornton, I., Persoone, G., Janssen, C., Godtfredsen, K., and Z'Graggen, M. N. (1996). International harmonization related to persistence and bioavailability. Human Ecol. Risk Assess. An Int. J. 2, 393-404. doi: 10.1080/10807039609383618

Che, D., Meagher, R. B., Heaton, A. C. P., Lima, A., Rugh, C. L., and Merkle, S. A. (2003). Expression of mercuric ion reductase in Eastern cottonwood (Populus deltoides) confers mercuric ion reduction and resistance. Plant Biotechnol. J. 1, 311-319. doi: 10.1046/j.1467-7652.2003.00031.x

Cherian, S., and Oliveira, M. M. (2005). Transgenic plants in phytoremediation: recent advances and new possibilities. Environ. Sci. Technol. 39, 9377-9390. doi: 10.1021/es0511341

Clemens, S., and Persoh, D. (2009). Multi-tasking phytochelatin synthases. Plant Sci. 177, 266-271. doi: 10.1016/j.plantsci.2009.06.008

Cristaldi, A., Conti, G. O., Jho, E. H., Zuccarello, P., Grasso, A., Copat, C., et al. (2017). Phytoremediation of contaminated soils by heavy metals and PAHs. A brief review. Environ. Technol. Innov. 8, 309-326. doi: 10.1016/j.eti.2017.08.002

Cunningham, S. D., Berti, W. R., and Huang, J. W. W. (1995). Phytoremediation of contaminated soils. Trends Biotechnol. 13, 393-397. doi: 10.1016/S0167-7799(00)88987-8

Cunningham, S. D., and Ow, D. W. (1996). Promises and prospects of phytoremediation. Plant Physiol. 110, 715-719. doi: 10.1104/pp.110.3.715

Curie, C., Panaviene, Z., Loulergue, C., Dellaporta, S. L., Briat, J.-F., and Walker, E. L. (2001). Maize yellow stripel encodes a membrane protein directly involved in Fe(III) uptake. Nature 409, 346-349. doi: 10.1038/35053080

de Borne, F. D., Elmayan, T., de Roton, C., de Hys, L., and Tepfer, M. (1998). Cadmium partitioning in transgenic tobacco plants expressing a mammalian metallothionein gene. Molecul. Breed. 4, 83-90. doi: 10.1023/A:1009669412489

Deblaere, R., Bytebier, B., De Greve, H., Deboeck, F., Schell, J., Van Montagu, M., et al. (1985). Efficient octopine Ti plasmid-derived vectors for Agrobacterium-mediated gene transfer to plants. Nucleic Acids Res. 13, 4777-4788. doi: 10.1093/nar/13.13.4777

Dhankher, O. P., Shasti, N. A., Rosen, B. P., Fuhrmann, M., and Meagher, R. B. (2003). Increased cadmium tolerance and accumulation by plants expressing bacterial arsenate reductase. N. Phytol. 159, 431-441. doi: 10.1046/j.1469-8137.2003.00827.x

Dixit, P., Singh, S., Vancheeswaran, R., Patnala, K., and Eapen, S. (2010). Expression of a Neurospora crassa zinc transporter gene in transgenic Nicotiana tabacum enhances plant zinc accumulation without co-transport of cadmium. Plant Cell Environ. 33, 1697-1707. doi: 10.1111/j.1365-3040.2010.02174.x

Dushenkov, V., Kumar, P., Motto, H., and Raskin, I. (1995). Rhizofiltration-the use of plants to remove heavy-metals from aqueous streams. Environ. Sci. Technol. 29, 1239-1245. doi: 10.1021/es00005a015

EFSA Panel On Geneticlay Modified Organisms (GMO) (2010). Guidance on the environmental risk assessment of genetically modified plants. EFSA J. 8:1879. doi: $10.2903 /$ j.efsa.2010.1879

Einspahr, D. W. (1976a). Influence of short-rotation forestry and paper quality. I, Short-rotation conifers. Tappi 59, 53-56.

Einspahr, D. W. (1976b). Influence of short-rotation forestry on pulp and paper quality. II, Short-rotation hardwood. Tappi 59, 63-66.

Evans, K. M., Gatehouse, J. A., Lindsay, W. P., Shi, J., Tommey, A. M., and Robinson, N. J. (1992). Expression of the pea metallothionein-like gene PsMTA in Escherichia coli and Arabidopsis thaliana and analysis of trace metal ion accumulation: implications for PsMTA function. Plant Mol. Biol. 20, 1019-1028. doi: 10.1007/BF00028889

Gomes, M. P., Marques, T. C. L. L. S. M., Carneiro, M. M. L. C., and Soares, Â. M. (2012). Anatomical characteristics and nutrient uptake and distribution associated with the Cd-phytoremediation capacity of Eucalyptus camaldulenses Dehnh. J. Soil Sci. Plant Nutr. 12, 481-496. doi: 10.4067/S0718-95162012005000010

Greger, M., and Landberg, T. (1999). Use of willow in phytoextraction. Int. J. Phytoremediation 1, 115-123. doi: 10.1080/15226519908500010

Grichko, V. P., Filby, B., and Glick, B. R. (2000). Increased ability of transgenic plants expressing the bacterial enzyme ACC deaminase to accumulate $\mathrm{Cd}, \mathrm{Co}, \mathrm{Cu}, \mathrm{Ni}, \mathrm{Pb}$, and $\mathrm{Zn}$. J. Biotechnol. 81, 45-53. doi: 10.1016/S0168-1656(00)00270-4

Grispen, V. M. J., Hakvoort, H. W. J., Bliek, T., Verkleij, J. A. C., and Schat, H. (2011). Combined expression of the Arabidopsis metallothionein MT2b and the heavy metal transporting ATPase HMA4 enhances cadmium tolerance and the root to shoot translocation of cadmium and zinc in tobacco. Environ. Exp. Bot. 72, 71-76. doi: 10.1016/j.envexpbot.2010.01.005

Guo, J., Dai, X., Xu, W., and Ma, M. (2008). Overexpressing GSH1 and AsPCS1 simultaneously increases the tolerance and accumulation of cadmium and arsenic in Arabidopsis thaliana. Chemosphere 72, 1020-1026. doi: 10.1016/j.chemosphere.2008.04.018

Ha, S. B., Smith, A. P., Howden, R., Dietrich, W. M., Bugg, S., O’Connell, M. J., et al. (1999). Phytochelatin synthase genes from Arabidopsis and the yeast Schizosaccharomyces pombe. Plant Cell 11, 1153-1164. doi: 10.1105/tpc.11.6.1153

Halpin, C. (2005). Gene stacking in transgenic plants-the challenge for 21st century plant biotechnology. Plant Biotechnol. J. 3, 141-155. doi: 10.1111/j.1467-7652.2004.00113.x

Hanikenne, M., Talke, I. N., Haydon, M. J., Lanz, C., Nolte, A., Motte, P., et al. (2008). Evolution of metal hyperaccumulation required cis-regulatory changes and triplication of HMA4. Nature 453, 391-395. doi: 10.1038/nature06877

He, Y. K., Sun, J. G., Feng, X. Z., Czako, M., and Marton, L. (2001). Differential mercury volatilization by tobacco organs expressing a modified bacterial merA gene. Cell Res. 11, 231-236. doi: 10.1038/sj.cr.7290091

Heaton, A. C. P., Rugh, C. L., Kim, T., Wang, N. J., and Meagher, R. B. (2003) Toward detoxifying mercury-polluted aquatic sediments with rice genetically engineered for mercury resistance. Environ. Toxicol. Chem. 22, 2940-2947. doi: 10.1897/02-442

Hilbeck, A., Meier, M., Römbke, J., Jänsch, S., Teichmann, H., and Tappeser, B. (2011). Environmental risk assessment of genetically modified plants-concepts and controversies. Environ. Sci. Eur. 23:13. doi: 10.1186/2190-4715-23-13

Hinchee, M., Rottmann, W., Mullinax, L., Zhang, C. S., Chang, S. J., Cunningham, M., et al. (2009). Short-rotation woody crops for bioenergy 
and biofuels applications. In Vitro Cell. Dev. Biol. Plant 45, 619-629. doi: 10.1007/s11627-009-9235-5

Hsieh, J. L., Chen, C. Y., Chiu, M. H., Chein, M. F., Chang, J. S., Endo, G., et al. (2009). Expressing a bacterial mercuric ion binding protein in plant for phytoremediation of heavy metals. J. Hazard. Mater. 161, 920-925. doi: 10.1016/j.jhazmat.2008.04.079

Ibañez, S., Talano, M., Ontanon, O., Suman, J., Medina, M. I., Macek, T., et al. (2016). Transgenic plants and hairy roots: exploiting the potential of plant species to remediate contaminants. N. Biotechnol. 33, 625-635. doi: 10.1016/j.nbt.2015.11.008

Ivanova, L. A., Ronzhina, D. A., Ivanov, L. A., Stroukova, L. V., Peuke, A. D., and Rennenberg, H. (2011). Over-expression of gsh1 in the cytosol affects the photosynthetic apparatus and improves the performance of transgenic poplars on heavy metal-contaminated soil. Plant Biol. 13, 649-659. doi: $10.1111 / j .1438-8677.2010 .00422 . x$

Jacobs, A., Drouet, T., Sterckeman, T., and Noret, N. (2017). Phytoremediation of urban soils contaminated with trace metals using Noccaea caerulescens: comparing non-metallicolous populations to the metallicolous 'Ganges' in field trials. Environ. Sci. Pollut. Res. Int. 24, 8176-8188. doi: 10.1007/s11356-017-8504-9

Jacobsen, E., and Schouten, H. J. (2009). Cisgenesis: an important subinvention for traditional plant breeding companies. Euphytica 170:235. doi: 10.1007/s10681-009-0037-y

Jaffré, T., Brooks, R. R., Lee, J., and Reeves, R. D. (1976). Sebertia acuminata: a hyperaccumulator of nickel from New Caledonia. Science 193, 579-580.

Kamthan, A., Chaudhuri, A., Kamthan, M., and Datta, A. (2016). Genetically modified (GM) crops: milestones and new advances in crop improvement. Theor. Appl. Genet. 129, 1639-1655. doi: 10.1007/s00122-016-2747-6

Kavuličová, J., Kaduková, J., and Ivánová, D. (2012). The evaluation of heavy metal toxicity in plants using the biochemical Tests. 11, 101-110. doi: 10.2478/v10296-012-0011-2

Kawashima, C. G., Noji, M., Nakamura, M., Ogra, Y., Suzuki, K. T., and Saito, K. (2004). Heavy metal tolerance of transgenic tobacco plants over-expressing cysteine synthase. Biotechnol. Lett. 26, 153-157. doi: 10.1023/B:BILE.0000012895.60773.ff

Khalid, S., Shahid, M., Niazi, N. K., Murtaza, B., Bibi, I., and Dumat, C. (2017). A comparison of technologies for remediation of heavy metal contaminated soils. J. Geochem. Explor. 182, 247-268. doi: 10.1016/j.gexplo.2016.11.021

Kidd, P., Mench, M., Alvarez-Lopez, V., Bert, V., Dimitriou, I., Friesl-Hanl, W., et al. (2015). Agronomic practices for improving gentle remediation of trace element-contaminated soils. Int. J. Phytoremediation 17, 1005-1037. doi: $10.1080 / 15226514.2014 .1003788$

Kille, P., Winge, D. R., Harwood, J. L., and Kay, J. (1991). A plants metallothionein produced in Escherichia coli. FEBS Lett. 295, 171-175. doi: 10.1016/0014-5793(91)81411-Z

Kim, Y. N., Kim, J. S., Seo, S. G., Lee, Y., Baek, S. W., Kim, I. S., et al. (2011). Cadmium resistance in tobacco plants expressing the MuSI gene. Plant Biotechnol. Rep. 5, 323-329. doi: 10.1007/s11816-011-0186-Z

Kiyono, M., Oka, Y., Sone, Y., Tanaka, M., Nakamura, R., Sato, M. H., et al. (2012). Expression of the bacterial heavy metal transporter MerC fused with a plant SNARE, SYP121, in Arabidopsis thaliana increases cadmium accumulation and tolerance. Planta 235, 841-850. doi: 10.1007/s00425-011-1543-4

Koprivova, A., Kopriva, S., Jager, D., Will, B., Jouanin, L., and Rennenberg, H. (2002). Evaluation of transgenic poplars over-expressing enzymes of glutathione synthesis for phytoremediation of cadmium. Plant Biol. 4, 664-670. doi: 10.1055/s-2002-37399

Kotrba, P., Najmanova, J., Macek, T., Ruml, T., and Mackova, M. (2009). Genetically modified plants in phytoremediation of heavy metal and metalloid soil and sediment pollution. Biotechnol. Adv. 27, 799-810. doi: 10.1016/j.biotechadv.2009.06.003

Krystofova, O., Zitka, O., Krizkova, S., Hynek, D., Shestivska, V., Adam, V., et al. (2012). Accumulation of cadmium by transgenic tobacco plants (Nicotiana tabacum $L$.) carrying yeast metallothionein gene revealed by electrochemistry. Int. J. Electrochem. Sci. 7, 886-907.

Krzciuk, K., and Gałuszka, A. (2015). Prospecting for hyperaccumulators of trace elements: a review. Crit. Rev. Biotechnol. 35, 522-532. doi: $10.3109 / 07388551.2014 .922525$
Krzesłowska, M. (2011). The cell wall in plant cell response to trace metals: polysaccharide remodeling and its role in defense strategy. Acta Physiol. Plant. 33, 35-51. doi: 10.1007/s11738-010-0581-z

Lang, M., Hao, M., Fan, Q., Wang, W., Mo, S., Zhao, W. C., et al. (2011). Functional characterization of BjCET3 and BjCET4, two new cation-efflux transporters from Brassica juncea L. J. Exp. Bot. 62, 4467-4480. doi: 10.1093/jxb/err137

Le Gall, H., Philippe, F., Domon, J.-M., Gillet, F., Pelloux, J., and Rayon, C. (2015). Cell wall metabolism in response to abiotic stress. Plants 4:112. doi: $10.3390 /$ plants 4010112

Lee, J., Bae, H., Jeong, J., Lee, J. Y., Yang, Y. Y., Hwang, I., et al. (2003). Functional expression of a bacteral heavy metal transporter in arabidopsis enhances resistance to and decrease uptake of heavy metals. Plant Physiol. 133, 589-596. doi: 10.1104/pp.103.021972

Leitenmaier, B., and Küpper, H. (2013). Compartmentation and complexation of metals in hyperaccumulator plants. Front. Plant Sci. 4:374. doi: $10.3389 /$ fpls.2013.00374

Leszczyszyn, O. I., Imam, H. T., and Blindauer, C. A. (2013). Diversity and distribution of plant metallothioneins: a review of structure, properties and functions. Metallomics 5, 1146-1169. doi: 10.1039/c3mt00072a

Li, J. C., Guo, J. B., Xu, W. Z., and Ma, M. (2006a). Enhanced cadmium accumulation in transgenic tobacco expressing the phytochelatin synthase gene of Cynodon dactylon L. J. Integr. Plant Biol. 48, 928-937. doi: 10.1111/j.1744-7909.2006.00314.x

Li, Y. J., Heaton, A. C. P., Carreira, L., and Meagher, R. B. (2006b). Enhanced tolerance to and accumulation of mercury, but not arsenic, in plants overexpressing two enzymes required for thiol peptide synthesis. Physiol. Plant. 128, 48-57. doi: 10.1111/j.1399-3054.2006.00732.x

Li, Z. S., Szczypka, M., Lu, Y. P., Thiele, D. J., and Rea, P. A. (1996). The yeast cadmium factor protein (YCF1) is a vacuolar glutathione S-conjugate pump. J. Biol. Chem. 271, 6509-6517. doi: 10.1074/jbc.271.11.6509

Liang Zhu, Y. Pilon-Smits, E. A. H., Jouanin, L., and Terry, N. (1999). Overexpression of glutathione synthetase in Indian mustard enhances cadmium accumulation and tolerance. Plant Physiol. 119, 73-79.

Liu, D., An, Z., Mao, Z., Ma, L., and Lu, Z. (2015). Enhanced heavy metal tolerance and accumulation by transgenic sugar beets expressing Streptococcus thermophilus StGCS-GS in the presence of $\mathrm{Cd}, \mathrm{Zn}$ and $\mathrm{Cu}$ alone or in combination. PLoS ONE 10:e0128824. doi: 10.1371/journal.pone.0128824

Liu, X., Wu, S., Xu, J., Sui, C., and Wei, J. (2017). Application of CRISPR/Cas9 in plant biology. Acta Pharm. Sin. B 7, 292-302. doi: 10.1016/j.apsb.2017.01.002

Liu, Z., Gu, C., Chen, F., Yang, D., Wu, K., Chen, S., et al. (2012). Heterologous expression of a Nelumbo nucifera phytochelatin synthase gene enhances cadmium tolerance in Arabidopsis thaliana. Appl. Biochem. Biotechnol. 166, 722-734. doi: 10.1007/s12010-011-9461-2

Macci, C., Doni, S., Peruzzi, E., Bardella, S., Filippis, G., Ceccanti, B., et al. (2013). A real-scale soil phytoremediation. Biodegradation 24, 521-538. doi: 10.1007/s10532-012-9608-z

Macci, C., Peruzzi, E., Doni, S., Poggio, G., and Masciandaro, G. (2016). The phytoremediation of an organic and inorganic polluted soil: a real scale experience. Int. J. Phytoremediation 18, 378-386. doi: $10.1080 / 15226514.2015 .1109595$

Macek, T., Kotrba, P., Svatos, A., Novakova, M., Demnerova, K., and Mackova, M. (2008). Novel roles for genetically modified plants in environmental protection. Trends Biotechnol. 26, 146-152. doi: 10.1016/j.tibtech.2007.11.009

Macek, T., Macková, M., and Kás, J. (2000). Exploitation of plants for the removal of organics in environmental remediation. Biotechnol. Adv. 18, 23-34. doi: 10.1016/S0734-9750(99)00034-8

Macek, T., Novakova, M., Kotrba, P., Viktorova, J., Lovecka, P., Fiser, J., et al. (2013). Genetically Modified Plants Designed for Phytoremediation of Toxic Organic And Inorganic Contaminants. Boca Raton, FL: Crc Press-Taylor \& Francis Group.

Macek, T., Uhlik, O., Jecna, K., Novakova, M., Lovecka, P., Rezek, J., et al. (2009). "Advances in phytoremediation and rhizoremediation," in Soil Biology, 17 Edn, ed A. Varma (Berlin: Springer), 257-277.

Mackova, M., Barriault, D., Francova, K., Sylvestre, M., Moder, M., Vrchotova, B., et al. (2006a). "Phytoremediation of polychlorinated biphenyls," in Focus on Biotechnology, 9A Edn., eds M. Mackova, D. Dowling, and T. Macek (Dordrecht: Springer), 143-167. 
Mackova, M., Dowling, D., and Macek, T. (2006b). Phytoremediation and Rhizoremediation. Theoretical Background. Dordrecht: Springer.

Marmiroli, N., Marmiroli, M., and Maestri, E. (2006). Phytoremediation and phytotechnologies: a review for the present and the future Soil Water Pollmoniter. Protec. Remed. 69, 403-416. doi: 10.1007/978-1-4020-4728-2_26

Martínez, M., Bernal, P., Almela, C., Vélez, D., García-Agustín, P., Serrano, R., et al. (2006). An engineered plant that accumulates higher levels of heavy metals than Thlaspi caerulescens, with yields of 100 times more biomass in mine soils. Chemosphere 64, 478-485. doi: 10.1016/j.chemosphere.2005.10.044

McGrath, S. P., and Zhao, F. J. (2003). Phytoextraction of metals and metalloids from contaminated soils. Curr. Opin. Biotechnol. 14, 277-282. doi: 10.1016/S0958-1669(03)00060-0

McGrath, S. P., Zhao, F. J., and Lombi, E. (2002). "Phytoremediation of metals, metalloids, and radionuclides," in Advances in Agronomy, ed D. L. Sparks (San Diego, CA; London: Academic Press Inc.,; Academic Press Ltd.), 92101-4495.

Meister, A. (1988). Glutathione metabolism and its selective modification. J. Biol. Chem. 263, 17205-17208.

Mench, M., Schwitzguébel, J. P., Schroeder, P., Bert, V., Gawronski, S., and Gupta, S. (2009). Assessment of successful experiments and limitations of phytotechnologies: contaminant uptake, detoxification and sequestration, and consequences for food safety. Environ. Sci. Pollut. Res. 16, 876-900. doi: 10.1007/s11356-009-0252-z

Milner, M. J., and Kochian, L. V. (2008). Investigating heavy-metal hyperaccumulation using Thlaspi caerulescens as a model system. Ann. Bot. 102, 3-13. doi: 10.1093/aob/mcn063

Mosa, K. A., Saadoun, I., Kumar, K., Helmy, M., and Dhankher, O. P. (2016). Potential biotechnological strategies for the cleanup of heavy metals and metalloids. Front. Plant Sci. 7:303. doi: 10.3389/fpls.2016.00303

Nishiyama, Y., Yanai, J., and Kosaki, T. (2005). Potential of Thlaspi caerulescens for cadmium phytoremediation: comparison of two representative soil types in Japan under different planting frequencies. Soil Sci. Plant Nutr. 51, 827-834. doi: 10.1111/j.1747-0765.2005.tb00117.x

Nixon, D. J., Stephens, W., Tyrrel, S. F., and Brierley, E. D. R. (2001). The potential for short rotation energy forestry on restored landfill caps. Bioresour. Technol. 77, 237-245. doi: 10.1016/S0960-8524(00)00081-X

Noctor, G., Strohm, M., Jouanin, L., Kunert, K. J., Foyer, C. H., and Rennenberg, H. (1996). Synthesis of glutathione in leaves of transgenic poplar overexpressing $\gamma$-glutamylcysteine synthetase. Plant Physiol. 112, 1071-1078. doi: $10.1104 /$ pp.112.3.1071

Palmgren, M. G., Clemens, S., Williams, L. E., Kraemer, U., Borg, S., Schjorring, J. K., et al. (2008). Zinc biofortification of cereals: problems and solutions. Trends Plant Sci. 13, 464-473. doi: 10.1016/j.tplants.2008.06.005

Pavlikova, D., Macek, T., Mackova, M., Sura, M., Szakova, J., and Tlustos, P. (2004). The evaluation of cadmium, zinc and nickel accumulation ability of transgenic tobacco bearing different transgenes. Plant Soil Environ. 50, 513-517. doi: 10.17221/4067-PSE

Peuke, A. D., and Rennenberg, H. (2005). Phytoremediation-Molecular biology, requirements for application, environmental protection, public attention and feasibility. EMBO Rep. 6, 497-501. doi: 10.1038/sj.embor.7400445

Pianelli, K., Mari, S., Marques, L., Lebrun, M., and Czernic, P. (2005). Nicotianamine over-accumulation confers resistance to nickel in Arabidopsis thaliana. Transg. Res. 14, 739-748. doi: 10.1007/s11248-005-7159-3

Pilon-Smits, E. A. H., Hwang, S. B., Lytle, C. M., Zhu, Y. L., Tai, J. C., Bravo, R. C., et al. (1999). Overexpression of ATP sulfurylase in Indian mustard leads to increased selenate uptake, reduction, and tolerance. Plant Physiol. 119, 123-132. doi: 10.1104/pp.119.1.123

Pilon-Smits, E. A. H., and Leduc, D. L. (2009). Phytoremediation of selenium using transgenic plants. Curr. Opin. Biotechnol. 20, 207-212. doi: 10.1016/j.copbio.2009.02.001

Postrigan, B. N., Knyazev, A. B., Kuluev, B. R., Yakhin, O. I., and Chemeris, A. V. (2012). Expression of the synthetic phytochelatin gene in tobacco. Russ. J. Plant Physiol. 59, 275-280. doi: 10.1134/S1021443712020136

Prasad, M. N. V., and Freitas, H. M. D. (2003). Metal hyperaccumulation in plants-biodiversity prospecting for phytoremediation technology. Electron. J. Biotechnol. 6, 285-321. doi: 10.2225/vol6-issue3-fulltext-6

Rascio, N., and Navari-Izzo, F. (2011). Heavy metal hyperaccumulating plants: how and why do they do it? and what makes them so interesting? Plant Sci. 180, 169-181. doi: 10.1016/j.plantsci.2010.08.016
Raskin, I., Smith, R. D., and Salt, D. E. (1997). Phytoremediation of metals: using plants to remove pollutants from the environment. Curr. Opin. Biotechnol. 8, 221-226. doi: 10.1016/S0958-1669(97)80106-1

Reeves, R. (2006). "Hyperaccumulation of trace elements by plants," in Phytoremediation of Metal-Contaminated Soils, eds J. L. Morel, G. Echevarria and N. Goncharova (Dordrecht: Springer), 25-52.

Reeves, R. D., Schwartz, C., Morel, J. L., and Edmondson, J. (2001). Distribution and metal-accumulating behavior of Thlaspi caerulescens and associated metallophytes in France. Int. J. Phytoremediation 3, 145-172. doi: 10.1080/15226510108500054

Rizwan, M., Ali, S., Qayyum, M. F., Ok, Y. S., Zia-ur-Rehman, M., Abbas, Z., et al. (2017). Use of Maize (Zea mays L.) for phytomanagement of Cdcontaminated soils: a critical review. Environ. Geochem. Health 39, 259-277. doi: 10.1007/s10653-016-9826-0

Robinson, B. H., Chiarucci, A., Brooks, R. R., Petit, D., Kirkman, J. H., Gregg, P. E. H., et al. (1997). The nickel hyperaccumulator plant Alyssum bertolonii as a potential agent for phytoremediation and phytomining of nickel. J. Geochem. Explor. 59, 75-86. doi: 10.1016/S0375-6742(97)00010-1

Robinson, B. H., Leblanc, M., Petit, D., Brooks, R. R., Kirkman, J. H., and Gregg, P. E. H. (1998). The potential of Thlaspi caerulescens for phytoremediation of contaminated soils. Plant Soil 203, 47-56. doi: 10.1023/A:1004328816645

Rodriguez, H., Vessely, S., Shah, S., and Glick, B. R. (2008). Effect of a nickel-tolerant ACC deaminase-producing Pseudomonas strain on growth of nontransformed and transgenic canola plants. Curr. Microbiol. 57, 170-174. doi: 10.1007/s00284-008-9181-1

Rudolph, A., Becker, R., Scholz, G., Procházka, Ž., Toman, J., Macek, T., et al. (1985). The occurrence of the amino acid nicotianamine in plants and microorganisms. A reinvestigation. Biochemie Physiologie der Pflanzen 180, 557-563. doi: 10.1016/S0015-3796(85)80036-6

Rugh, C. L., Wilde, H. D., Stack, N. M., Thompson, D. M., Summers, A. O., and Meagher, R. B. (1996). Mercuric ion reduction and resistance in transgenic Arabidopsis thaliana plants expressing a modified bacterial merA gene. Proc. Natl. Acad. Sci. U.S.A. 93, 3182-3187. doi: 10.1073/pnas.93.8.3182

Sahi, S. V., Bryant, N. L., Sharma, N. C., and Singh, S. R. (2002). Characterization of a lead hyperaccumulator shrub, Sesbania drummondii. Environ. Sci. Technol. 36, 4676-4680. doi: 10.1021/es020675x

Salt, D. E., Blaylock, M., Kumar, N., Dushenkov, V., Ensley, B. D., Chet, I., et al. (1995). Phytoremediation-a novel strategy for the removal of toxic metals from the environment using plants. Biotechnology 13, 468-474.

Salt, D. E., Smith, R. D., and Raskin, I. (1998). Phytoremediation. Annu. Rev. Plant Physiol. Plant Mol. Biol. 49, 643-668. doi: 10.1146/annurev.arplant.49.1.643

Sandermann, H. (1994). Higher-plant metabolism of xenobioticsthe green liver concept. Pharmacogenetics 4, 225-241. doi: 10.1097/00008571-199410000-00001

Sanvido, O., Romeis, J., Gathmann, A., Gielkens, M., Raybould, A., and Bigler, F. (2012). Evaluating environmental risks of genetically modified crops: ecological harm criteria for regulatory decision-making. Environ. Sci. Policy 15, 82-91. doi: 10.1016/j.envsci.2011.08.006

Sarma, H. (2011). Metal hyperaccumulation in plants: a review focusing on phytoremediation technology. J. Environ. Sci. Technol. 4, 118-138. doi: $10.3923 /$ jest.2011.118.138

Sasaki, Y., Hayakawa, T., Inoue, C., Miyazaki, A., Silver, S., and Kusano, T. (2006). Generation of mercury-hyperaccumulating plants through transgenic expression of the bacterial mercury membrane transport protein MerC. Transgenic Res. 15, 615-625. doi: 10.1007/s11248-006-9008-4

Schnoor, J. L., Light, L. A., McCutcheon, S. C., Wolfe, N. L., and Carreia, L. H. (1995). Phytoremediation of organic and nutrient contaminants. Environ. Sci. Technol. 29, 318A-323A. doi: 10.1021/es00007a747

Sheoran, V., Sheoran, A. S., and Poonia, P. (2009). Phytomining: a review. Miner. Eng. 22, 1007-1019. doi: 10.1016/j.mineng.2009.04.001

Shim, D., Kim, S., Choi, Y.-I., Song, W.-Y., Park, J., Youk, E. S., et al. (2013). Transgenic poplar trees expressing yeast cadmium factor 1 exhibit the characteristics necessary for the phytoremediation of mine tailing soil. Chemosphere 90, 1478-1486. doi: 10.1016/j.chemosphere.2012.09.044

Shukla, D., Kesari, R., Mishra, S., Dwivedi, S., Tripathi, R. D., Nath, P., et al. (2012). Expression of phytochelatin synthase from aquatic macrophyte Ceratophyllum demersum L. enhances cadmium and arsenic accumulation in tobacco. Plant Cell Rep. 31, 1687-1699. doi: 10.1007/s00299-012-1283-3 
Silver, S., and Phung le, T. (2005). A bacterial view of the periodic table: genes and proteins for toxic inorganic ions. J. Indust. Microbiol. Biotechnol. 32, 587-605. doi: 10.1007/s10295-005-0019-6

Silver, S., and Phung, L. T. (2005). Genes and enzymes involved in bacterial oxidation and reduction of inorganic arsenic. Appl. Environ. Microbiol. 71, 599-608. doi: 10.1128/AEM.71.2.599-608.2005

Singh, S., Parihar, P., Singh, R., Singh, V. P., and Prasad, S. M. (2016). Heavy metal tolerance in plants: role of transcriptomics, proteomics, metabolomics, and ionomics. Front. Plant Sci. 6:1143. doi: 10.3389/fpls.2015.01143

Singh, S. P., Keller, B., Gruissem, W., and Bhullar, N. K. (2017). Rice NICOTIANAMINE SYNTHASE 2 expression improves dietary iron and zinc levels in wheat. Theor. Appl. Genet. 130, 283-292. doi: 10.1007/s00122-016-2808-x

Sorrentino, M. C., Capozzi, F., Amitrano, C., Giordano, S., Arena, C., and Spagnuolo, V. (2018). Performance of three cardoon cultivars in an industrial heavy metal-contaminated soil: effects on morphology, cytology and photosynthesis. J. Hazard. Mater. 351, 131-137. doi: 10.1016/j.jhazmat.2018.02.044

Suman, J., Kotrba, P., and Macek, T. (2014). Putative P-1B-type ATPase from the bacterium Achromobacter xylosoxidans A8 alters $\mathrm{Pb} 2+/ \mathrm{Zn} 2+/ \mathrm{Cd} 2+-$ resistance and accumulation in Saccharomyces cerevisiae. Biochim. Biophys. Acta-Biomemb. 1838, 1338-1343. doi: 10.1016/j.bbamem.2014. 01.023

Suryawanshi, V., Talke, I. N., Weber, M., Eils, R., Brors, B., Clemens, S., et al. (2016). Between-species differences in gene copy number are enriched among functions critical for adaptive evolution in Arabidopsis halleri. BMC Genomics 17: 1034. doi: 10.1186/s12864-016-3319-5

Tangahu, B. V., Sheikh Abdullah, S. R., Basri, H., Idris, M., Anuar, N., and Mukhlisin, M. (2011). A review on heavy metals (As, Pb, and $\mathrm{Hg}$ ) uptake by plants through phytoremediation. Int. J. Chem. Eng. 2011:939161. doi: $10.1155 / 2011 / 939161$

Thomas, J. C., Davies, E. C., Malick, F. K., Endreszl, C., Williams, C. R., Abbas, M., et al. (2003). Yeast metallothionein in transgenic tobacco promotes copper uptake from contaminated soils. Biotechnol. Prog. 19, 273-280. doi: $10.1021 / \mathrm{bp} 025623 \mathrm{q}$

Tommey, A. M., Shi, J., Lindsay, W. P., Urwin, P. E., and Robinson, N. J. (1991). Expression of the pea gene PSMTA in E. coli. Metal-binding properties of the expressed protein. FEBS Lett. 292, 48-52.

Trijatmiko, K. R., Dueñas, C., Tsakirpaloglou, N., Torrizo, L., Arines, F. M., Adeva, C., et al. (2016). Biofortified indica rice attains iron and zinc nutrition dietary targets in the field. Sci. Rep. 6:19792. doi: 10.1038/srep19792

Tsatsakis, A. M., Nawaz, M. A., Kouretas, D., Balias, G., Savolainen, K., Tutelyan, V. A., et al. (2017). Environmental impacts of genetically modified plants: a review. Environ. Res. 156, 818-833. doi: 10.1016/j.envres.2017.03.011

Unterbrunner, R., Puschenreiter, M., Sommer, P., Wieshammer, G., Tlustoš, P., Zupan, M., et al. (2007). Heavy metal accumulation in trees growing on contaminated sites in Central Europe. Environ. Pollut. 148, 107-114. doi: $10.1016 /$ j.envpol.2006.10.035

van der Ent, A., Baker, A. J. M., Reeves, R. D., Pollard, A. J., and Schat, H. (2013). Hyperaccumulators of metal and metalloid trace elements: facts and fiction. Plant Soil 362, 319-334. doi: 10.1007/s11104-012-1287-3

Van Slycken, S., Witters, N., Meers, E., Peene, A., Michels, E., Adriaensen, K., et al. (2013a). Safe use of metal-contaminated agricultural land by cultivation of energy maize (Zea mays). Environ. Pollut. 178, 375-380. doi: 10.1016/j.envpol.2013.03.032

Van Slycken, S., Witters, N., Meiresonne, L., Meers, E., Ruttens, A., Van Peteghem, P., et al. (2013b). Field evaluation of willow under short rotation coppice for phytomanagement of metal-polluted agricultural soils. Int. J. Phytoremediation 15, 677-689. doi: 10.1080/15226514.2012.723070

Vangronsveld, J., Herzig, R., Weyens, N., Boulet, J., Adriaensen, K., Ruttens, A., et al. (2009). Phytoremediation of contaminated soils and groundwater: lessons from the field. Environ. Sci. Pollut. Res. 16, 765-794. doi: 10.1007/s11356-009-0213-6

Verbruggen, N., Hermans, C., and Schat, H. (2009). Molecular mechanisms of metal hyperaccumulation in plants. N. Phytol. 181, 759-776. doi: $10.1111 / j .1469-8137.2008 .02748 . x$
Volk, T. A., Verwijst, T., Tharakan, P. J., Abrahamson, L. P., and White, E. H. (2004). Growing fuel: a sustainability assessment of willow biomass crops. Front. Ecol. Environ. 2, 411-418. doi: 10.1890/15409295(2004)002[0411:GFASAO]2.0.CO;2

Vyslouzilova, M., Puschenreiter, M., Wieshammer, G., and Wenzel, W. W. (2006). Rhizosphere characteristics, heavy metal accumulation and growth performance of two willow (Salix $x$ rubens) clones. Plant Soil Environ. 52, 353-361. doi: 10.17221/3452-PSE

Wang, L., Ji, B., Hu, Y., Liu, R., and Sun, W. (2017). A review on in situ phytoremediation of mine tailings. Chemosphere 184, 594-600. doi: 10.1016/j.chemosphere.2017.06.025

Wojas, S., Hennig, J., Plaza, S., Geisler, M., Siemianowski, O., Sklodowska, A., et al. (2009). Ectopic expression of Arabidopsis ABC transporter MRP7 modifies cadmium root-to-shoot transport and accumulation. Environ. Pollut. 157, 2781-2789. doi: 10.1016/j.envpol.2009.04.024

Wu, Q., Shigaki, T., Williams, K. A., Han, J. S., Kim, C. K., Hirschi, K. D., et al. (2011). Expression of an Arabidopsis $\mathrm{Ca} 2+/ \mathrm{H}+$ antiporter CAX1 variant in petunia enhances cadmium tolerance and accumulation. J. Plant Physiol. 168, 167-173. doi: 10.1016/j.jplph.2010.06.005

Wu, T.-Y., Gruissem, W., and Bhullar, N. K. (2018). Facilitated citrate-dependent iron translocation increases rice endosperm iron and zinc concentrations. Plant Sci. 270, 13-22. doi: 10.1016/j.plantsci.2018.02.002

Xiao, S., Gao, W., Chen, Q. F., Ramalingam, S., and Chye, M. L. (2008). Overexpression of membrane-associated acyl-CoA-binding protein ACBP1 enhances lead tolerance in Arabidopsis. Plant J. 54, 141-151. doi: $10.1111 / j .1365-313 X .2008 .03402 . x$

Xu, W., Lu, G., Dang, Z., Liao, C., Chen, Q., and Yi, X. (2013). Uptake and distribution of $\mathrm{Cd}$ in sweet maize grown on contaminated soils: a field-scale study. Bioinorgan. Chem. Appl. 2013:959764. doi: 10.1155/2013/959764

Yankov, B., Delibaltova, V., and Bojinov, M. (2000). Contents of Cu, Zn, Cd and Pb in the vegetative organs of cotton cultivars from industrially polluted region. Rasteniev"dni Nauki 37, 525-531.

Zhang, H. Y., Xu, W. Z., Dai, W. T., He, Z. Y., and Ma, M. (2006). Functional characterization of cadmium-responsive garlic gene AsMT2b: a new member of metallothionein family. Chinese Sci. Bull. 51, 409-416. doi: 10.1007/s11434-006-0409-9

Zhang, Y., Zhao, L. H., Wang, Y., Yang, B. Y., and Chen, S. Y. (2008). Enhancement of heavy metal accumulation by tissue specific co-expression of iaaM and ACC deaminase genes in plants. Chemosphere 72, 564-571. doi: 10.1016/j.chemosphere.2008.03.043

Zhao, C., Qiao, M., Yu, Y., Xia, G., and Xiang, F. (2010). The effect of the heterologous expression of Phragmites australis gamma-glutamylcysteine synthetase on the $\mathrm{Cd} 2+$ accumulation of Agrostis palustris. Plant Cell Environ. 33, 877-887. doi: 10.1111/j.1365-3040.2009.02113.x

Zheljazkov, V. D., and Nielsen, N. E. (1996a). Effect of heavy metals on peppermint and cornmint. Plant Soil 178, 59-66. doi: 10.1007/BF00011163

Zheljazkov, V. D., and Nielsen, N. E. (1996b). Studies on the effect of heavy metals $(\mathrm{Cd}, \mathrm{Pb}, \mathrm{Cu}, \mathrm{Mn}, \mathrm{Zn}$ and $\mathrm{Fe}$ ) upon the growth, productivity and quality of lavender (Lavandula angustifolia Mill.) production. J. Essent. Oil Res. 8, 259-274.

Zhu, Y. L., Pilon-Smits, E. A. H., Tarun, A. S., Weber, S. U., Jouanin, L., and Terry, N. (1999). Cadmium tolerance and accumulation in Indian mustard is enhanced by overexpressing $\gamma$-glutamylcysteine synthetase. Plant Physiol. 121, $1169-1177$.

Conflict of Interest Statement: The authors declare that the research was conducted in the absence of any commercial or financial relationships that could be construed as a potential conflict of interest.

Copyright (c) 2018 Suman, Uhlik, Viktorova and Macek. This is an open-access article distributed under the terms of the Creative Commons Attribution License (CC BY). The use, distribution or reproduction in other forums is permitted, provided the original author(s) and the copyright owner(s) are credited and that the original publication in this journal is cited, in accordance with accepted academic practice. No use, distribution or reproduction is permitted which does not comply with these terms. 